\title{
Survei Keterampilan Gerak Dasar Lokomotor Nonlokomotor dan Manipulatif Siswa Putra Kelas 7 MTs
}

\author{
Catur Prima Eka Putra Abdullah*, Siti Nurrochmah \\ Universitas Negeri Malang, Jl. Semarang No. 5 Malang, Jawa Timur, Indonesia \\ *Penulis korespondensi, Surel: caturprima3@gmail.com
}

Paper received: 3-5-2021; revised: 24-5-2021; accepted: 28-5-2021

\begin{abstract}
Abstrak
Keterampilan gerak dasar yaitu keterampilan yang melibatkan aspek afektif, kognitif dan psikomotor yang digunakan untuk mencapai sebuah latihan atau tujuan gerakan seperti, melempar, melompat atau meloncat dan menjaga keseimbangan. Keterampilan gerak dasar dibagi menjadi tiga bagian keterampilan gerak, yaitu: (1) kemampuan gerak lokomotor (locomotor skills), (2) kemampuan gerak nonlokomotor (nonlocomotor skills), (3) kemampuan gerak manipulatif (manipulative skills), permasalahan dalam proses pembelajaran pendidikan jasmani di MTs Negeri 1 Kota Malang ketika awal pembelajaran keterampilan melempar bola ke gawang pada siswa putra tidak dapat melakukan secara tepat ke sasaran dan cenderung tidak bisa mengontrol gerakannya.. Penelitian ini bertujuan untuk mengkaji dan memperoleh informasi tentang kemampuan gerak dasar lokomotor, nonlokomotor dan manipulatif siswa putra kelas 7 MTs Negeri 1 Kota Malang. Penelitian ini menggunakan rancangan survei bentuk deskriptif kuantitatif. Subjek penelitian berjumlah 92 orang siswa kelas 7 MTs Negeri 1 Kota Malang. Pengumpulan data menggunakan teknik pengukuran bentuk tes kemampuan gerak dasar locomotor, nonlokomotor dan manipulatif. Hasil analisis data pada siswa putra kelas 7 MTs Negeri 1 Kota Malang untuk aspek Kemampuan gerak dasar lokomotor yang dibagi menjadi 3 unsur gerak yaitu lari,lompat dan loncat. Lari 1555 persen dan lari zig-zag 8 persen, lompat gawang $20 \mathrm{~cm}$ ke samping kiri-kanan satu kaki 57 persen dan lompat gawang $20 \mathrm{~cm}$ ke depan bolak-balik tumpuan satu kaki 60 persen. Dan loncat side hop jump 58 persen dan loncat knee tuck jump 55 persen. (2) Kemampuan gerak dasar nonlokomotor yang dibagi 2 unsur gerak yaitu sit and reach 20 persen dan back up lengan 21 persen. (3) Kemampuan gerak dasar manipulatif yang dibagi menjadi 3 unsur gerak yaitu lempar tangkap bola tenis 30 persen, dribble bola basket 76 persen, dan lempar bola ke sasaran 53 persen.
\end{abstract}

Kata kunci: Gerak dasar; locomotor; nonlokomotor; manipulatif

\section{Pendahuluan}

Pendidikan jasmani merupakan bentuk pendidikan yang menggunakan aktivitas fisik sebagai media, berarti pembelajaran pendidikan jasmani tidak hanya mengembangkan kemampuan fisik dan motorik siswa saja, tetapi juga melalui aktivitas fisik dipilih dan dikemas secara baik disertai dengan penggunaan pendekatan metodik yang tepat, diharapkan dapat dikembangkan melalui seluruh aspek yang dimiliki oleh anak didik. Melalui aktivitas fisik yang demikian, diharapkan siswa tidak hanya memiliki kemampuan fisik dan motorik yang baik, melainkan juga mempunyai kemampuan kognitif dan afektif yang diharapkan, sehingga hal ini berakibat pada aspek pertumbuhan dan perkembangan siswa yang dapat berjalan dengan semestinya. Mulyanto (2014) berpendapat bahwa pendidikan jasmani merupakan proses belajar untuk bergerak dan belajar melalui gerak. Ciri dari pendidikan jasmani adalah belajar melalui pengalaman gerak untuk mencapai tujuan pengajaran melalui pelaksanaan, aktivitas jasmani, bermain dan olahraga. Dengan demikian melalui pendidikan jasmani siswa dapat mempelajari hal-hal yang sangat penting dan bermanfaat bagi tubuhnya seperti memperoleh berbagai keterampilan efektif yang berhubungan dengan sikap dan perilaku, kognitif keterampilan dalam berpikir, dan psikomotor yaitu keterampilan yang berkaitan dengan 
keterampilan gerak. Pendidikan jasmani adalah usaha dengan menggunakan aktivitas otototot besar hingga proses pendidikan yang berlangsung tidak terhambat oleh gangguan kesehatan dan pertumbuhan badan.Pendidikan jasmani sebagai salah satu mata pelajaran penting bagi pertumbuhan dan perkembangan siswa, untuk itu pendidikan jasmani harus disajikan di sekolah dasar. Mata pelajaran tersebut merupakan bagian pokok dari upaya pendidikan secara keseluruhan. Sudah sebaiknya jika harus diajarkan dengan sungguhsungguh, seperti halnya mata pelajaran lainnya (Rahyubi, 2011). Pembelajaran pada kelas 7 melakukan proses transisi (peralihan) dari tingkat SD ke tingkat jenjang yang lebih tinggi yaitu sekolah menengah pertama (SMP). Pendidikan jenjang SMP pembelajaran PJOK juga diberikan, untuk menguasai berbagai keterampilan dibutuhkan kondisi keterampilan gerak dasar. Pada jenjang pendidikan sekolah dasar, pembelajaran bercirikan anak suka bergerak, jika memasuki pembelajaran di jenjang sekolah menengah pertama. Aktivitas pembelajaran gerak dilakukan di tingkat SD sangat berguna untuk diaplikasikan dalam pembelajaran PJOK.

Rahyubi (2012) menyatakan bahwa hakikat dari belajar sendiri memiliki arti proses berlangsungnya hidup yang secara sadar atau tidak harus dijalani semua manusia untuk mencapai berbagai macam kompetensi, pengetahuan, keterampilan, dan sikap yang telah dilakukan. Pembelajaran merupakan usaha yang dilakukan oleh pendidik kepada peserta didik agar seorang peserta didik mampu belajar dengan baik. Proses belajar kan terjadi sepanjang hayat seorang individu serta dapat berlaku di manapun dan kapanpun (Suardi 7).

Pembelajaran Pendidikan Jasmani, Olahraga dan Kesehatan (PJOK) merupakan pembelajaran yang unik dan bercirikan pembelajaran yang fokusnya lebih banyak pada pembelajaran jasmani dan melibatkan aktivitas jasmani atau bentuk gerak. Guru Pendidikan Jasmani dan Olahraga, semestinya berupaya menciptakan pembelajaran yang menarik minat siswa untuk belajar secara optimal dalam rangka mencapai tujuan pembelajaran yang diharapkan. Oleh karena itu, ketika pembelajaran berlangsung materi yang diberikan sebaiknya yang mampu untuk memajukan aktivitas jasmaninya. Tujuan pembelajaran pendidikan jasmani adalah meningkatkan kemampuan dan keterampilan gerak dasar. Dalam materi keterampilan gerak dasar, siswa dituntut untuk mampu menguasai beberapa keterampilan gerak dasar yang salah satunya yaitu keterampilan gerak dasar lokomotor, gerak dasar lokomotor ini sendiri adalah aktivitas yang paling sering dilakukan oleh anak yaitu gerakan jalan, lari, lompat, dan loncat. Dalam kehidupan sehari-hari, manusia dari usia anakanak hingga dewasa selalu melakukan kegiatan dengan gerak dasar. Keterampilan gerak dasar yaitu keterampilan yang melibatkan aspek afektif, kognitif dan psikomotor yang digunakan untuk mencapai sebuah latihan atau tujuan gerakan seperti, melempar, melompat atau meloncat dan menjaga keseimbangan (Syahrial, 2015). Untuk mencapai tujuan tersebut, dibutuhkan unsur kemampuan gerak dasar dengan bantuan guru siswa harus bisa menyerap pengetahuan tentang olahraga yang diberikan oleh guru melalui pembelajaran tentang gerak. Selain itu, siswa harus sering melakukan olahraga untuk membiasakan diri. Dengan demikian siswa secara alami belajar gerak dengan terbiasa melakukan olahraga.

Kemampuan gerak dasar merupakan perkembangan unsur kematangan pengendalian tubuh. Kemampuan gerak dasar sangat dibutuhkan bagi setiap individu termasuk siswa untuk menunjang berbagai keterampilan olahraga. Jika pembelajaran pendidikan jasmani di SD dilakukan secara optimal, maka siswa yang melanjutkan studi ke jenjang pendidikan menengah pertama akan mempelajari berbagai keterampilan gerak dasar termasuk teknik dalam bidang olahraga sehingga tingkat kemampuan gerak dasar tubuh sangat penting untuk 
menunjang pembelajaran tersebut. Seorang siswa harus menguasai kemampuan gerak dasar yang akan menunjang berbagai aktivitas olahraga seperti berbagai jenis keterampilan dalam olahraga. dapat memperoleh hasil yang maksimal Kemampuan gerak dasar yang dimiliki dapat diaplikasikan atau digunakan dalam pembelajaran PJOK di jenjang berikutnya. ketika pembelajaran PJOK, yaitu untuk mendukung dan menunjang pembelajaran beberapa keterampilan teknik dasar dalam olahraga. Gerak dasar berkaitan dengan kegiatan manusia melakukan pekerjaan dan bergerak, tetapi gerak dasar yang digunakan manusia dalam melakukan pekerjaan masing-masing berbeda-beda. Gerak dasar yang digunakan oleh seorang siswa dan orang dewasa berbeda. Gerak dasar sangat besar manfaatnya bagi pertumbuhan dan perkembangan siswa, karena tercapainya tujuan dari sebuah lembaga pendidikan salah satunya karena status aspek gerak dasar tersebut tergolong baik. Dalam pendidikan jasmani kemampuan gerak dasar masuk ke dalam aspek motorik. Widiastuti (2015) mengungkapkan bahwa kemampuan motorik sebagai suatu kapasitas dari seseorang yang berhubungan dengan aktivitas fisik untuk melaksanakan suatu gerakan. Hanief \& Sugito (2015) keterampilan gerak dasar dibagi menjadi tiga bagian keterampilan gerak, yaitu: (1) kemampuan gerak locomotor (locomotor skills), (2) kemampuan gerak nonlokomotor (nonlocomotor skills), (3) kemampuan gerak manipulatif (manipulative skills). Oleh karena itu, kemampuan gerak dasar yang diperoleh dari pembelajaran di tingkat SD sangat berguna untuk pembelajaran di tingkat sekolah menengah, semestinya guru penting untuk mengetahui kondisi kemampuan gerak dasar. Akan tetapi pada kenyataannya guru jarang melakukan pengukuran terhadap unsur gerak dasar di sekolah MTs Negeri 1 Kota Malang. Berdasarkan hasil observasi dan wawancara kepada guru mata pelajaran pendidikan jasmani kesehatan dan olahraga MTs Negeri 1 Kota Malang khususnya siswa putra di kelas 7 , hingga saat ini guru belum pernah melakukan pengukuran terhadap kemampuan gerak dasar di kelas 7 yang memasuki masa transisi dari tingkat SD, pengukuran awal terhadap kemampuan gerak dasar motorik adalah sangat penting untuk menentukan langkah-langkah pembelajaran selanjutnya dan memperlancar proses pembelajaran (Nurrochmah, 2016). Oleh karena itu, menawarkan kepada guru MTs Negeri 1 Kota Malang untuk mengadakan pengukuran dalam bentuk tes terhadap aspek-aspek kemampuan gerak dasar. Di samping itu pula penulis menemukan permasalahan dalam proses pembelajaran pendidikan jasmani ketika awal pembelajaran keterampilan melempar bola ke gawang pada siswa putra tidak dapat melakukan secara tepat ke sasaran dan cenderung tidak bisa mengontrol gerakannya.

Gerak motorik dibedakan dari jenis kelamin laki-laki dan perempuan. Jenis kelamin seorang anak berpengaruh terhadap perkembangan langsung dan tidak langsung. Pengaruh secara langsung terjadi sebelum dan setelah lahir, dan pengaruh tidak langsung berasal dari perkembangan kondisi hormon. Pada dasarnya perkembangan motoric anak laki-laki dan perempuan sama, namun anak laki-laki cenderung lebih aktif dalam gerak. Anak laki-laki lebih banyak melakukan gerakan dibanding anak perempuan. Yudrik Jahja (2011) menyimpulkan bahwa terdapat beberapa perbedaan pokok yaitu, 1) anak laki-laki lebih banyak bermain di luar dibandingkan dengan anak perempuan, 2) anak laki-laki bermain dalam kelompok yang lebih besar dibanding dengan anak perempuan, 3) permainan anak laki-laki terjadi dalam kelompok yang terdiri dari berbagai usia, 4) anak perempuan sering memainkan permainan anak laki-laki daripada anak laki-laki memainkan permainan anak perempuan, 5) anak lakilaki lebih banyak memainkan permainan yang bersifat pertandingan daripada anak perempuan, 6) permainan anak laki-laki berlangsung lebih lama daripada permainan anak perempuan. Dari penjelasan perbedaan gerak anak laki-laki dan perempuan diatas dapat 
disimpulkan bahwa anak laki-laki lebih banyak melakukan aktivitas, bermain, dari pengalaman bermain tidak heran jika anak laki-laki akan lebih mengalami luka pada tubuhnya, hal itulah yang menyebabkan anak laki-laki lebih handal dalam melakukan gerak dibandingkan dengan anak perempuan.

\section{Metode}

Penelitian ini menggunakan rancangan survei. Maolani \& Cahyana (2015:81) "menyatakan bahwa penelitian survei adalah suatu bentuk koleksi yang direncanakan untuk tujuan menjelaskan/menerangkan, yakni mempelajari fenomena sosial dengan menganalisis hubungan antara variabel-variabel tertentu". Ditinjau dari tujuan penelitian, maka penelitian ini termasuk jenis penelitian deskriptif. Nazir (2014:75) "mengatakan bahwa penelitian deskriptif ditujukan untuk mendeskripsikan/menggambarkan atau menjelaskan secara akurat tentang sifat-sifat dari beberapa fenomena yang ada, baik fenomena kelompok atau individu yang bersifat alamiah ataupun rekayasa manusia dengan interpretasi yang tepat". Variabel yang diteliti berupa keterampilan gerak dasar lokomotor, nonlokomotor, dan manipulatif pada siswa putra kelas 7 MTs Negeri 1 Kota Malang. Populasi dalam penelitian ini adalah siswa putra kelas 7 MTs Negeri 1 Kota Malang berjumlah 92 siswa putra. Sampel yang digunakan diambil dengan menggunakan teknik purposive proporsional random sampling yaitu teknik penentuan sampel dengan menggunakan pertimbangan atau tujuan tertentu berdasar pada ciri-ciri atau karakteristik siswa (Sugiyono,2009:96) dengan porsi 75\% dari 122 orang siswa. Dalam penelitian ini teknik pengambilan tersebut berdasar pada tujuan penelitian dan karakteristik siswa putra yaitu siswa baru kelas 7 tahun akademik 2019/2020. Adapun jumlah kelas dan siswa yang terlibat dalam penelitian ini yaitu empat kelas tiap kelas berjumlah 30-32 orang, sehingga sampel dalam penelitian ini berjumlah keseluruhan 92 orang. Instrumen yang digunakan dalam penelitian ini berupa instrumen tes dan non tes (Nurrochmah, 2016:7). Tes yang digunakan untuk memperoleh data keterampilan gerak dasar lokomotor berupa tes, pada unsur lari menggunakan tes: (a) kemampuan lari 15 meter dan (b) kemampuan lari zig-zag bentuk M, pada unsur loncat meliputi (a) kemampuan loncat side hop jump dan (b) kemampuan loncat knee tuck jump, dan unsur lompat meliputi (a) kemampuan lompat gawang $20 \mathrm{~cm}$ ke samping kiri-kanan tumpuan satu kaki dan (b) kemampuan lompat gawang $20 \mathrm{~cm}$ ke depan bolak-balik tumpuan satu kaki. Keterampilan gerak dasar nonlokomotor berupa tes: (a) kemampuan sit and reach dan (b) kemampuan back up lengan. Keterampilan gerak dasar manipulatif berupa tes: (a) kemampuan lempar meliputi lempar tangkap bola tenis, (b) kemampuan dribble bola basket dan (c) kemampuan lempar bola ke sasaran. Tes tersebut dilaksanakan pada subjek siswa putra kelas 7 MTs Negeri 1 Kota Malang. Sedangkan instrumen non-tes yang digunakan di dalam penelitian ini berupa observasi (pengamatan) yang dilengkapi dengan pedoman observasi pelaksanaan keterampilan gerak dasar lokomotor tes kemampuan lari, lompat, dan loncat. Keterampilan gerak dasar nonlokomotor meliputi kemampuan tes sit and reach dan back up lengan. Keterampilan gerak dasar manipulatif berupa kemampuan tes lempar tangkap bola ke dinding, dribble bola basket dan lempar bola ke sasaran gawang futsal pada masing-masing siswa dan mencatat sesegera mungkin hasil tes yang dilakukan oleh setiap siswa. Adapun sarana yang digunakan adalah: bola tenis, bola basket, cone, peluit, stopwatch, dll, sedangkan prasarana yang digunakan adalah lapangan basket. Teknik pengumpulan data pada penelitian ini dengan menggunakan metode tes. Untuk metode pelaksanaan pengumpulan menggunakan teknik pengukuran (Baumgartner \& Hensly, 2007:72) bentuk tes yaitu keterampilan gerak dasar lokomotor berupa kemampuan tes lari, lompat, dan loncat, keterampilan gerak dasar nonlokomtor berupa kemampuan tes sit and 
reach dan back up angkat bahu dan lengan, keterampilan gerak dasar manipulatif berupa kemampuan tes lempar tangkap bola, dribble bola basket dan lempar bola ke sasaran pada gawang futsal untuk siswa putra kelas 7 MTs Negeri 1 Kota Malang. Analisis data yang digunakan dalam penelitian ini berupa teknik analisis statistika deskriptif ukuran tendency central yang meliputi mean, median (Kadir, 2015:57-58) dan modus yaitu gejala/frekuensi yang sering muncul dan sebagai nilai rata-rata jika data bentuk kualitatif (Kamid, 2017: 4.22), ukuran dispersi (variabilitas) (Mairing, 2017:54,60) meliputi ukuran standar deviasi, variansi dan koefisien variansi (Kadir, 2018:70). Teknik analisis data tersebut digunakan untuk mengetahui kondisi kemampuan keterampilan gerak dasar lokomotor, nonlokomotor, dan manipulatif pada siswa putra kelas 7 MTs Negeri 1 Kota Malang.

\section{Hasil dan Pembahasan}

\subsection{Hasil}

Tabel 1. Penyajian Deskripsi Data Kemampuan Gerak Dasar Aspek Lokomotor Meliputi Unsur Lari, Lompat dan Loncat dari Siswa Putra Kelas 7 MTs I Kota Malang

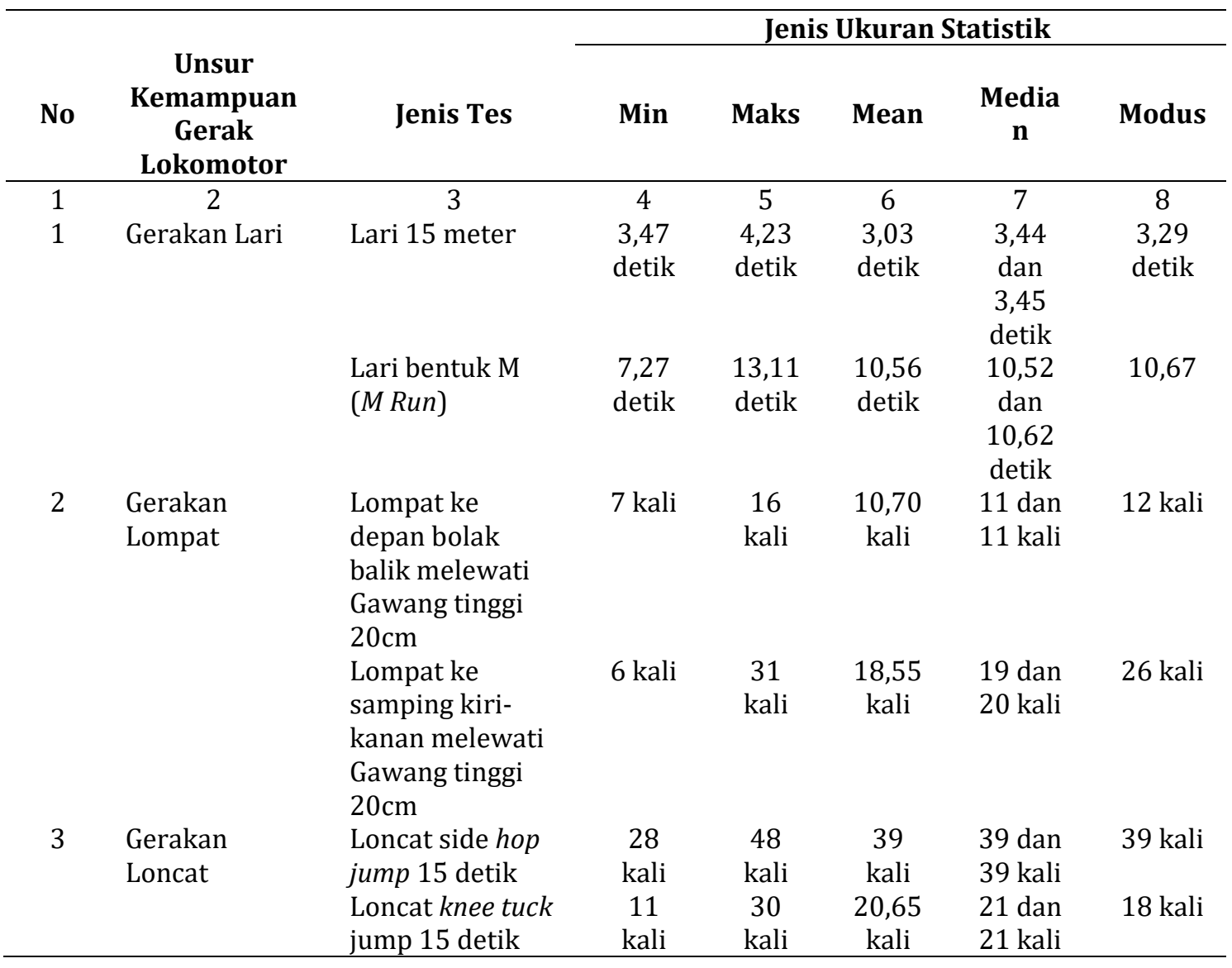

Berdasarkan sajian deskripsi data pada Tabel 1 tersebut di atas, bahwa data dari Siswa Putra kelas 7 MTs I Kota Malang yang berjumlah 92 orang dapat dikemukakan bahwa pada tes gerakan lokomotor pada unsur yaitu (1) lari yang terdiri atas dua macam butir tes yaitu (a) tes lari 15 meter diperoleh hasil skor minimum 3,03 detik dan maksimum 4,23 detik, rata-rata hitung 3,47 detik, modus (frekuensi yang paling banyak muncul) analisis data menggunakan 
distribusi frekuensi tunggal 3,29 detik (data riil) dan median analisis data menggunakan distribusi frekuensi tunggal berada pada kedudukan urutan 46 dan 47 diperoleh skor 3,44 dan 3,45 detik (data riil). (b) tes lari zig-zag bentuk M ( M run) diperoleh hasil skor minimum 7,27 detik dan maksimum 13,11 detik, rata-rata hitung 10,56 detik, modus (frekuensi yang paling banyak muncul) analisis data menggunakan distribusi frekuensi tunggal diperoleh hasil 10,67 detik (data riil) dan median analisis data menggunakan distribusi frekuensi tunggal berada pada kedudukan urutan 46 dan 47 diperoleh skor 10,52 dan 10,62 detik (data riil). Gerakan lokomotor unsur (2) lompat yang terdiri atas dua buah butir tes yaitu (a) bentuk tes lompat gawang bolak balik setinggi $20 \mathrm{~cm}$ selama 15 detik diperoleh hasil skor minimum 7 kali dan maksimum 16 kali, rata-rata hitung 10,70 kali, modus (frekuensi yang paling banyak muncul) analisis data menggunakan distribusi frekuensi tunggal diperoleh hasil 12 kali (data riil) dan median analisis data menggunakan distribusi frekuensi tunggal berada pada kedudukan urutan 46 dan 47 diperoleh skor 11 dan 11 kali (data riil). (b) kemampuan gerakan lompat gawang ke samping setinggi $20 \mathrm{~cm}$ selama 15 detik diperoleh hasil skor minimum 6 kali dan maksimum 31 kali, rata-rata hitung 18,55 kali, modus (frekuensi yang paling banyak muncul) menggunakan distribusi frekuensi tunggal 26 kali (data riil) dan median analisis data menggunakan distribusi frekuensi tunggal berada pada kedudukan urutan 46 dan 47 diperoleh skor 19 dan 20 kali (data riil). Gerakan lokomotor unsur (c) kemampuan gerakan loncat terdiri dari dua butir tes yaitu (a) tes side hop jump selama 15 detik diperoleh hasil skor minimum 28 kali dan maksimum 48 kali, rata-rata hitung 39 kali, modus (frekuensi yang paling banyak muncul) analisis data menggunakan distribusi frekuensi tunggal diperoleh hasil 39 kali (data riil) dan median menggunakan distribusi frekuensi tunggal berada pada kedudukan urutan 46 dan 47 diperoleh skor 39 dan 39 kali (data riil). (b) gerakan tes knee tuck jump selama 15 detik diperoleh hasil skor minimum 11 kali dan maksimum 30 kali, rata-rata hitung 20,65 kali, modus (frekuensi yang paling banyak muncul) analisis data menggunakan distribusi frekuensi tunggal diperoleh hasil 18 kali (data riel) dan median menggunakan distribusi frekuensi tunggal berada pada kedudukan urutan 46 dan 47 diperoleh skor 21 dan 21 kali (data riil).

Tabel 2. Penyajian Deskripsi Data Kemampuan Gerak Dasar Aspek Gerakan Nonlokomotor dan Manipulatif pada Siswa Putra Kelas 7 MTs I Kota Malang

\begin{tabular}{|c|c|c|c|c|c|c|c|}
\hline \multirow[b]{2}{*}{ No } & \multirow[b]{2}{*}{$\begin{array}{c}\text { Unsur } \\
\text { Kemampuan } \\
\text { Gerak } \\
\text { Lokomotor }\end{array}$} & \multirow[b]{2}{*}{ Jenis Tes } & \multicolumn{5}{|c|}{ Jenis Ukuran Statistik } \\
\hline & & & Min & Maks & Mean & Median & Modus \\
\hline \multirow[t]{3}{*}{1} & 2 & 3 & 4 & 5 & 6 & 7 & 8 \\
\hline & $\begin{array}{l}\text { Gerakan } \\
\text { Nonlokomotor }\end{array}$ & Sit and reach & $4 \mathrm{~cm}$ & $18 \mathrm{~cm}$ & $\begin{array}{c}9,85 \\
\mathrm{~cm}\end{array}$ & $\begin{array}{c}8 \mathrm{~cm} \text { dan } \\
8 \mathrm{~cm}\end{array}$ & $7 \mathrm{~cm}$ \\
\hline & & Back up lengan & $7 \mathrm{~cm}$ & $19 \mathrm{~cm}$ & $\begin{array}{c}12,08 \\
\mathrm{~cm}\end{array}$ & $\begin{array}{c}12 \mathrm{~cm} \\
\text { dan } 12 \\
\mathrm{~cm}\end{array}$ & $10 \mathrm{~cm}$ \\
\hline \multirow[t]{2}{*}{2} & $\begin{array}{l}\text { Gerakan } \\
\text { manipulatif }\end{array}$ & $\begin{array}{l}\text { Lempar } \\
\text { tangkap bola } \\
\text { tenis ke dinding } \\
15 \text { detik }\end{array}$ & 6 kali & $\begin{array}{c}14 \\
\text { kali }\end{array}$ & $\begin{array}{l}9,31 \\
\text { kali }\end{array}$ & $\begin{array}{c}9 \text { kali } \\
\text { dan } 9 \\
\text { kali }\end{array}$ & 8 kali \\
\hline & & $\begin{array}{l}\text { Dribble bola } \\
\text { basket }\end{array}$ & $\begin{array}{l}3,02 \\
\text { detik }\end{array}$ & $\begin{array}{r}6,49 \\
\text { detik }\end{array}$ & $\begin{array}{c}3,77 \\
\text { detik }\end{array}$ & $\begin{array}{c}3,4 \text { detik } \\
\text { dan } 3,4 \\
\text { detik }\end{array}$ & $\begin{array}{l}3,11 \\
\text { detik }\end{array}$ \\
\hline
\end{tabular}




\begin{tabular}{|c|c|c|c|c|c|c|c|}
\hline \multirow[b]{2}{*}{ No } & \multirow[b]{2}{*}{$\begin{array}{c}\text { Unsur } \\
\text { Kemampuan } \\
\text { Gerak } \\
\text { Lokomotor }\end{array}$} & \multirow[b]{2}{*}{ Jenis Tes } & \multicolumn{5}{|c|}{ Jenis Ukuran Statistik } \\
\hline & & & Min & Maks & Mean & Median & Modus \\
\hline & & $\begin{array}{l}\text { Lempar bola ke } \\
\text { sasaran }\end{array}$ & $\begin{array}{c}4 \\
\text { poin }\end{array}$ & $\begin{array}{c}10 \\
\text { poin }\end{array}$ & $\begin{array}{l}6,83 \\
\text { poin }\end{array}$ & $\begin{array}{c}7 \text { poin } \\
\text { dan } 7 \\
\text { poin }\end{array}$ & 6 poin \\
\hline
\end{tabular}

Berdasarkan sajian deskripsi data pada Tabel 2 tersebut di atas, data yang diperoleh dari Siswa Putra kelas 7 MTs I Kota Malang berjumlah 92 orang dapat dikemukakan bahwa pada kemampuan gerakan nonlokomotor yang terdiri atas dua macam butir tes yaitu (a) gerakan sit and reach diperoleh hasil skor minimum $4 \mathrm{~cm}$ dan maksimum $18 \mathrm{~cm}$, rata-rata hitung 9,85 cm, modus (frekuensi yang paling banyak muncul) analisis data menggunakan distribusi frekuensi tunggal $7 \mathrm{~cm}$ (data riil) dan median analisis data menggunakan distribusi frekuensi tunggal berada pada kedudukan urutan 46 dan 47 yaitu skor 8 dan $8 \mathrm{~cm}$ (data riil). (b) tes gerakan back up lengan diperoleh hasil skor minimum $15 \mathrm{~cm}$ dan maksimum $39 \mathrm{~cm}$, rata-rata hitung $29,77 \mathrm{~cm}$, modus (frekuensi yang paling banyak muncul) analisis data menggunakan distribusi frekuensi tunggal diperoleh hasil $30 \mathrm{~cm}$ (data riil) dan median analisis data menggunakan distribusi frekuensi tunggal berada pada kedudukan urutan 46 dan 47 diperoleh skor $30 \mathrm{~cm}$ dan $30 \mathrm{~cm}$ (data riil). Tes kemampuan gerakan manipulatif yang terdiri atas tiga buah butir tes yaitu (a) tes gerakan lempar tangkap bola tenis ke dinding selama 15 detik diperoleh hasil skor minimum 6 kali dan maksimum 14 kali, rata-rata hitung 9,315 kali, modus (frekuensi yang paling banyak muncul) analisis data menggunakan distribusi frekuensi tunggal diperoleh hasil 8 kali (data riil) dan median analisis data menggunakan distribusi frekuensi tunggal berada pada kedudukan urutan 46 dan 47 diperoleh hasil yaitu 9 dan 9 kali (data riil). (b) kemampuan gerakan dribble bola basket zig-zag diperoleh hasil skor minimum 3,02 dan maksimum 6,49 detik, rata-rata hitung 3,77 detik, modus (frekuensi yang paling banyak muncul) analisis data menggunakan distribusi frekuensi tunggal 3,11 detik (data riil) dan median analisis data menggunakan distribusi frekuensi tunggal berada pada kedudukan urutan 46 dan 47 diperoleh skor 3,4 detik dan 3,4 detik (data riil). (c) tes kemampuan gerakan lempar bola ke sasaran diperoleh hasil skor minimum 4 poin dan maksimum 10 poin, rata-rata hitung 6,83 poin, modus (frekuensi yang paling banyak muncul) analisis data menggunakan distribusi frekuensi tunggal diperoleh hasil 6 poin (data riil) dan median menggunakan distribusi frekuensi tunggal berada pada kedudukan urutan 46 dan 47 diperoleh skor yaitu 7 poin dan 7 poin (data riil).

\begin{tabular}{|c|c|c|c|c|c|c|c|}
\hline \multirow[b]{2}{*}{ No } & \multirow[b]{2}{*}{$\begin{array}{c}\text { Gerak Dasar } \\
\text { Lokomotor } \\
\text { Unsur }\end{array}$} & \multirow[b]{2}{*}{ Jenis Tes } & \multicolumn{5}{|c|}{ Jenis Ukuran Statistik } \\
\hline & & & $\bar{X}$ & SD & Varian & $\begin{array}{c}\text { KV } \\
(\%)\end{array}$ & Keterangan \\
\hline 1 & 2 & 3 & 4 & 5 & 6 & 7 & 8 \\
\hline \multirow[t]{2}{*}{1} & Lari & Lari 15 detik & $\begin{array}{c}3,47 d \\
\text { etik }\end{array}$ & $\begin{array}{c}0,29 \\
\text { detik }\end{array}$ & $\begin{array}{c}0,08 \\
\text { detik }\end{array}$ & $8,6 \%$ & Concentred \\
\hline & & Lari Bentuk $M$ & $\begin{array}{l}10,56 \\
\text { detik }\end{array}$ & $\begin{array}{r}0,86 \\
\text { detik }\end{array}$ & $\begin{array}{c}0,74 \\
\text { detik }\end{array}$ & $8,2 \%$ & Heterogen \\
\hline 2 & Lompat & $\begin{array}{l}\text { Lompat } \\
\text { Gawang Bolak } \\
\text { balik setinggi } \\
20 \mathrm{~cm} 15 \text { detik }\end{array}$ & $\begin{array}{c}10,70 \\
\text { kali }\end{array}$ & $\begin{array}{l}2,22 \\
\text { kali }\end{array}$ & $\begin{array}{l}4,93 \\
\text { kali }\end{array}$ & $20,7 \%$ & Concentred \\
\hline
\end{tabular}




\begin{tabular}{|c|c|c|c|c|c|c|c|}
\hline \multirow[b]{2}{*}{ No } & \multirow[b]{2}{*}{$\begin{array}{l}\text { Gerak Dasar } \\
\text { Lokomotor } \\
\text { Unsur }\end{array}$} & \multirow[b]{2}{*}{ Jenis Tes } & \multicolumn{5}{|c|}{ Jenis Ukuran Statistik } \\
\hline & & & $\overline{\boldsymbol{X}}$ & SD & Varian & $\begin{array}{c}\mathrm{KV} \\
(\%)\end{array}$ & Keterangan \\
\hline \multirow{3}{*}{3} & \multirow{3}{*}{ Loncat } & $\begin{array}{l}\text { Lompat } \\
\text { Gawang } \\
\text { samping } \\
\text { setinggi } 20 \mathrm{~cm} \\
15 \text { detik }\end{array}$ & $\begin{array}{c}10,79 \\
\text { kali }\end{array}$ & $\begin{array}{r}2,52 \\
\text { kali }\end{array}$ & $\begin{array}{l}6,36 \\
\text { kali }\end{array}$ & $23,37 \%$ & Heterogen \\
\hline & & Knee Tuck Jump & $\begin{array}{c}20,65 \\
\text { kali }\end{array}$ & $\begin{array}{r}4,53 \\
\text { kali }\end{array}$ & $\begin{array}{c}20,58 \\
\text { kali }\end{array}$ & $21,97 \%$ & Heterogen \\
\hline & & Side Hop Jump & $\begin{array}{c}39 \\
\text { kali }\end{array}$ & $\begin{array}{r}4,80 \\
\text { kali }\end{array}$ & $\begin{array}{c}23,09 \\
\text { kali }\end{array}$ & $12,3 \%$ & Heterogen \\
\hline $\begin{array}{l}\text { Ket } \\
\overline{\boldsymbol{X}} \\
\text { SD } \\
\text { KV }\end{array}$ & $\begin{array}{l}\text { angan: } \\
\text { : rata-rata hitu } \\
\text { : standart devi } \\
\text { : koefisien ker }\end{array}$ & $\begin{array}{l}\text { si (simpangan baku) } \\
\text { gaman }\end{array}$ & & & & & \\
\hline
\end{tabular}

Berdasarkan sajian hasil analisis data pada Tabel 3 tersebut di atas, bahwa data yang diperoleh dari Siswa Putra kelas 7 MTs I Kota Malang yang berjumlah 92 orang dianalisis menggunakan statistika deskriptif bentuk penyebaran data hasil tes gerakan lokomotor pada unsur yaitu (1) lari yang terdiri atas dua macam butir tes yaitu (a) tes lari 15 meter diperoleh hasil rata-rata hitung 3,47 detik, skor simpangan baku (SB) 0,29 detik, skor, varian sampel 0,08 detik, dan koefisien varian $9 \%$. (b) tes lari bentuk M (M run) diperoleh hasil skor ratarata hitung 10,56761 detik, skor simpangan baku (SB) 0,83 detik, skor varian sampel 0,744 detik, dan koefisien varian $8 \%$. (2) unsur gerakan lompat yang terdiri atas dua buah butir tes yaitu (a) bentuk tes lompat gawang bolak balik setinggi $20 \mathrm{~cm}$ selama 15 detik diperoleh hasil rata-rata hitung 10,70 detik, skor simpangan baku (SB) 2,22 detik, skor, varian sampel 4,93 detik, dan koefisien varian $21 \%$ dan (b) kemampuan gerakan lompat gawang ke samping setinggi $20 \mathrm{~cm}$ selama 15 detik diperoleh hasil rata-rata hitung 18,55 detik, skor simpangan baku (SB) 6,39 detik, skor varian sampel 40,93 detik, dan koefisien varian $34 \%$. Gerakan unsur (3) gerakan loncat terdiri dari dua butir tes yaitu (a) tes side hop jump selama 15 detik diperoleh hasil rata-rata hitung 39 detik, skor simpangan baku (SB) 4,80 detik, skor varian sampel 23,09 detik, dan koefisien varian $12 \%$ dan (b) gerakan tes knee tuck jump selama 15 detik diperoleh hasil rata-rata hitung 20,65 detik, skor simpangan baku (SB) 4,53 detik, skor varian sampel 20,58 detik, dan koefisien varian $22 \%$.

Tabel 4 Distribusi Frekuensi Relatif dan Kriteria Tes Lari 15 Meter Siswa Putra Kelas 7 MTs I Kota Malang

\begin{tabular}{cccc}
\hline Interval & Fo & FR & Keterangan \\
\hline $2,88-3,17$ & 16 & $17 \%$ & Baik Sekali \\
$2,18-3,47$ & 35 & $38 \%$ & Baik \\
$3,48-3,77$ & 26 & $28 \%$ & Cukup \\
$3,78-4,07$ & 8 & $9 \%$ & Kurang Baik \\
$4,08-4,37$ & 7 & $8 \%$ & Tidak Baik \\
\hline
\end{tabular}

Berdasarkan sajian hasil analisis deskripsi bentuk persentase pada Tabel 4 data hasil tes lari 15 m dari Siswa Putra Kelas 7 MTs I Kota Malang yang berjumlah 92 orang disajikan bentuk distribusi frekuensi terdiri dari 5 kelas masing-masing kelas berinterval 0,3 detik. Masing- 
masing kelas mempunyai frekuensi dan setiap kelas yang berfrekuensi (f) dibagi dengan jumlah seluruh peserta tes 92 orang peserta. Mengacu distribusi frekuensi bergolong tersebut pada Tabel 4.4 tersebut, dapat dikemukakan bahwa kelas 2,88 - 3,17 mempunyai $\mathrm{f}=16$ dari 92 orang dan besarnya persentase $=17 \%$ sebagai skor persentase terendah dan kelas 4,08 4,37 jumlah $\mathrm{f}=7$ dan persentase $=8 \%$.

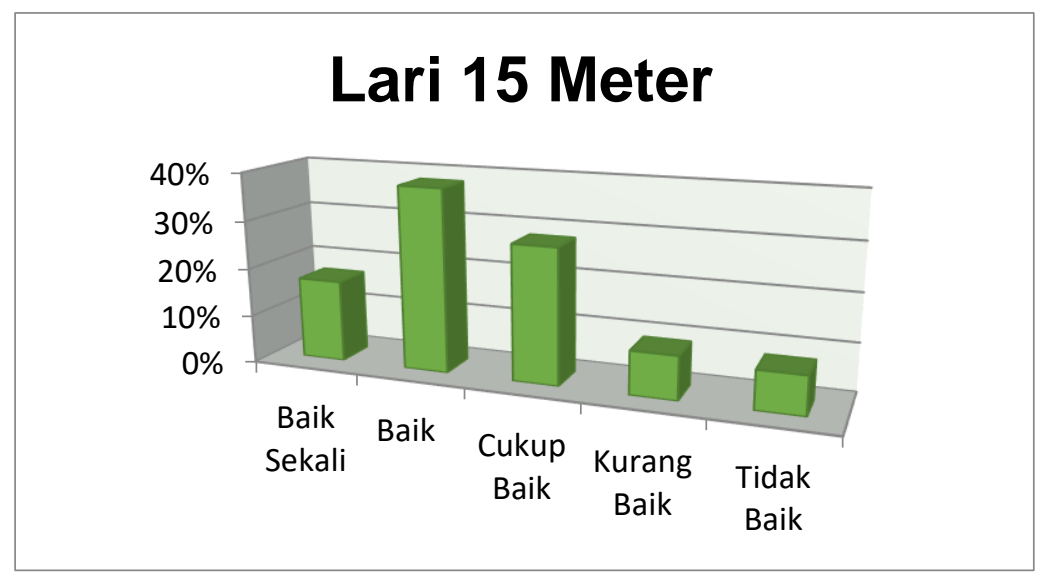

\section{Gambar 1. Sajian Hasil Analisis Data Bentuk Frekunensi Relatif Hasil Tes Lari 15 Meter}

Berdasarkan data yang disajikan dalam bentuk Grafik 1 tersebut dapat dijelaskan bahwa data yang dianalisis melalui frekuensi relatif diantara skor-skor yang masuk dalam kelas-kelas frekuensi yang paling menonjol adalah pada kelas baik yaitu Fo berjumlah 35 (38\%) dari 92 orang dan pada kelas tidak baik Fo yang jumlahnya paling kecil yaitu berjumlah 7 (8\%) dari 92 orang. Merujuk pada Tabel 4 tersebut, dapat dikemukakan bahwa berdasarkan hasil tes lari 15 meter keadaan keterampilan gerak lari pada Siswa Putra Kelas 7 MTs I Kota Malang dominan kriteria baik sekali 17\%, baik 38\%, cukup baik 28\%, kurang baik $9 \%$ dan siswa yang berada di kriteria tidak baik hanya $7 \%$.

Tabel 5. Distribusi Frekuensi Relatif dan Kriteria Tes Lari Bentuk M (M Run) Data Siswa Putra Kelas 7 MTs I Kota Malang

\begin{tabular}{cccc}
\hline Interval & Fo & FR & Keterangan \\
\hline$<8,84$ & 4 & $4 \%$ & Baik Sekali \\
$8,85-9,70$ & 4 & $4 \%$ & Baik \\
$9,71-10,57$ & 37 & $40 \%$ & Cukup \\
$10,58-11,43$ & 39 & $42 \%$ & Kurang Baik \\
$11,44>$ & 8 & $9 \%$ & Tidak Baik \\
\hline
\end{tabular}

Berdasarkan sajian hasil analisis deskripsi bentuk persentase pada Tabel 5 data hasil tes lari bentuk M (M run) dari Siswa Putra Kelas 7 MTs I Kota Malang yang berjumlah 92 orang disajikan bentuk distribusi frekuensi terdiri dari 5 kelas masing-masing kelas berinterval 0,86 detik. Masing-masing kelas mempunyai frekuensi dan setiap kelas yang berfrekuensi (f) dibagi dengan jumlah seluruh peserta tes 92 orang peserta. Mengacu distribusi frekuensi bergolong tersebut pada Tabel 5 tersebut, dapat dikemukakan bahwa kelas baik sekali $<8,84$ mempunyai $\mathrm{f}=4$ dari 92 orang dengan besar persentase $=4 \%$ dan kelas baik 8,85 -9.70 mempunyai $\mathrm{f}=4$ dari 92 orang dengan besar persentase $4 \%$ sebagai skor persentase terendah serta kelas kurang baik 10,57 $-11,42$ jumlah $\mathrm{f}=39$ dari 92 orang dengan persentase $=42 \%$ sebagai skor tertinggi. 


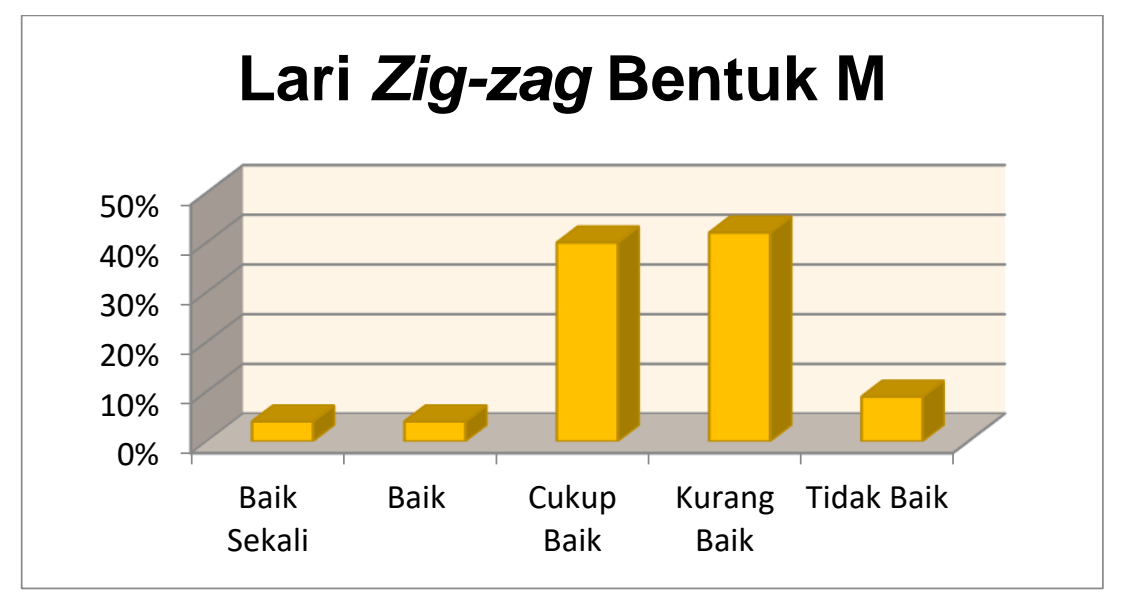

\section{Gambar 2. Sajian Hasil Analisis Data Bentuk Frekunensi Relatif dan Norma Kriteria Tes Hasil Tes Lari Bentuk M (M Run)}

Berdasarkan data yang disajikan dalam bentuk Grafik 2 tersebut dapat dijelaskan bahwa data yang dianalisis melalui frekuensi relatif diantara skor-skor yang masuk dalam kelas-kelas frekuensi yang paling menonjol adalah pada kelas kurang baik yaitu Fo berjumlah 39 (42\% ) dari 92 orang dan pada kelas baik sekali dan baik yaitu Fo yang jumlahnya paling kecil yaitu 4 (4\%) dari 92 orang. Merujuk pada Tabel 5 tersebut, dapat dikemukakan bahwa berdasarkan hasil tes lari bentuk M (M Run) keadaan keterampilan gerak lari bentuk M 9m Run) pada Siswa Putra Kelas 7 MTs I Kota Malang dominan berada pada kriteria baik sekali 4\%, baik 4\%, cukup baik $40 \%$, kurang baik $42 \%$ dan siswa yang berada di kriteria tidak baik $9 \%$.

Tabel 6. Distribusi Frekuensi Relatif dan Kriteria Tes Lompat Gawang $20 \mathrm{Cm}$ Ke Depan Bolak-balik Data Siswa Putra Kelas 7 MTs I Kota Malang

\begin{tabular}{|c|c|c|c|}
\hline Interval & Fo & FR & Keterangan \\
\hline $15-17$ & 18 & $20 \%$ & Baik Sekali \\
\hline $12-14$ & 37 & $40 \%$ & Baik \\
\hline $9-11$ & 33 & $36 \%$ & Cukup baik \\
\hline $6-8$ & 4 & $4 \%$ & Kurang Baik \\
\hline
\end{tabular}

Berdasarkan sajian hasil analisis deskripsi bentuk persentase pada Tabel 6 data hasil tes lompat gawang $20 \mathrm{~cm}$ ke depan bolak-balik dari Siswa Putra Kelas 7 MTs I Kota Malang yang berjumlah 92 orang disajikan bentuk distribusi frekuensi terdiri dari 4 kelas masing-masing kelas berinterval 3 kali. Masing-masing kelas mempunyai frekuensi dan setiap kelas yang berfrekuensi (f) dibagi dengan jumlah seluruh peserta tes 92 orang peserta. Mengacu distribusi frekuensi bergolong tersebut pada Tabel 6tersebut, dapat dikemukakan bahwa kelas baik 12 14 mempunyai $\mathrm{f}=37$ dari 92 orang dengan besar persentase $40 \%$ sebagai skor persentase tertinggi dan kelas kurang baik $6-8$ jumlah $f=4$ dari 92 orang dengan persentase $=4 \%$ sebagai skor terrendah. 


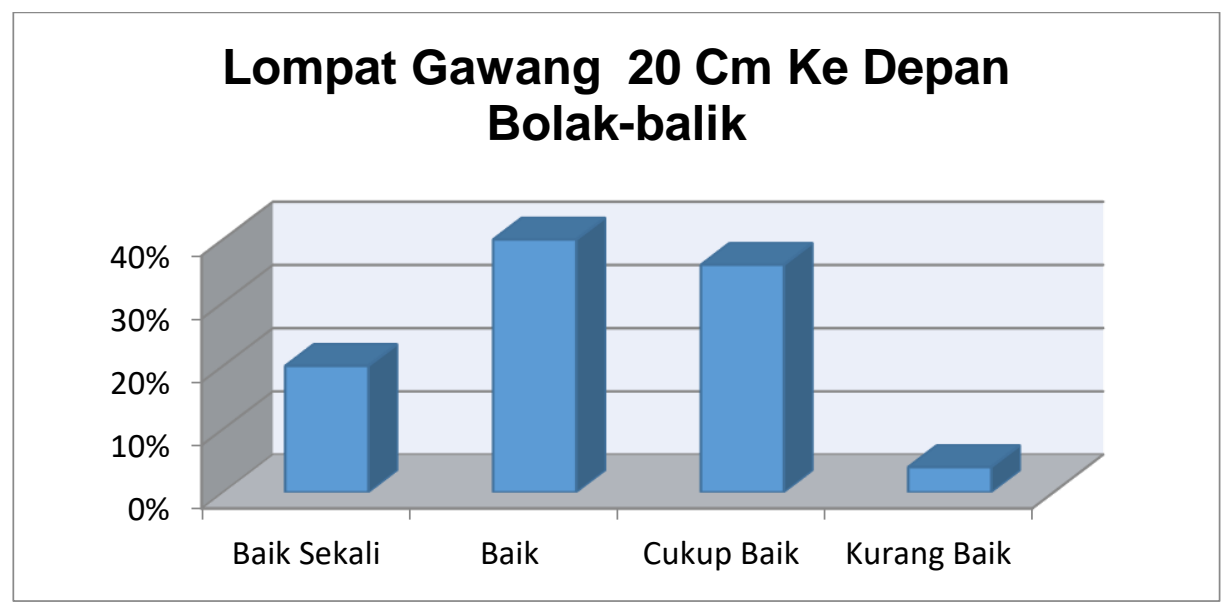

Grafik 3 Sajian Hasil Analisis Data Bentuk Frekunensi Relatif dan Norma Kriteria Tes Hasil Tes Lompat Gawang $20 \mathrm{Cm}$ Ke Depan Bolak-balik

Berdasarkan data yang disajikan dalam bentuk Grafik 3 tersebut dapat dijelaskan bahwa data yang dianalisis melalui frekuensi relatif diantara skor-skor yang masuk dalam kelas-kelas frekuensi yang paling menonjol adalah pada kelas baik yaitu Fo berjumlah 37 (40\%) dari 92 orang dan pada kurang baik yaitu Fo yang jumlahnya paling kecil yaitu 4 (4\%) dari 92 orang. Merujuk pada Tabel 6 tersebut, dapat dikemukakan bahwa berdasarkan hasil tes lompat gawang $20 \mathrm{~cm}$ ke depan bolak-balik keadaan keterampilan gerak lompat gawang $20 \mathrm{~cm}$ ke depan bolak-balik pada Siswa Putra Kelas 7 MTs I Kota Malang dominan berada pada kriteria baik sekali $20 \%$, baik $40 \%$, cukup baik $36 \%$, dan kurang baik $4 \%$.

Tabel 7. Distribusi Frekuensi Relatif dan Kriteria Tes Lompat Gawang $20 \mathrm{Cm}$ Ke Depan Bolak-balik Data Siswa Putra Kelas 7 MTs I Kota Malang

\begin{tabular}{cccc}
\hline Interval & Fo & FR & Keterangan \\
\hline $14-16$ & 11 & $12 \%$ & Baik Sekali \\
$11-13$ & 41 & $45 \%$ & Baik \\
$8-10$ & 30 & $33 \%$ & Cukup baik \\
$5-7$ & 10 & $11 \%$ & Kurang Baik \\
\hline
\end{tabular}

Berdasarkan sajian hasil analisis deskripsi bentuk persentase pada Tabel 7 data hasil tes lompat gawang $20 \mathrm{~cm}$ ke samping kiri-kanan dari Siswa Putra Kelas 7 MTs I Kota Malang yang berjumlah 92 orang disajikan bentuk distribusi frekuensi terdiri dari 4 kelas masing-masing kelas berinterval 2 kali. Masing-masing kelas mempunyai frekuensi dan setiap kelas yang berfrekuensi (f) dibagi dengan jumlah seluruh peserta tes 92 orang peserta. Mengacu distribusi frekuensi bergolong tersebut pada Tabel 7 tersebut, dapat dikemukakan bahwa kelas baik 11 - 13 mempunyai $f=41$ dari 92 orang dengan besar persentase $45 \%$ sebagai skor persentase tertinggi dan kelas kurang baik $5-7$ jumlah $\mathrm{f}=10$ dari 92 orang dengan persentase $=11 \%$ sebagai skor terendah. 


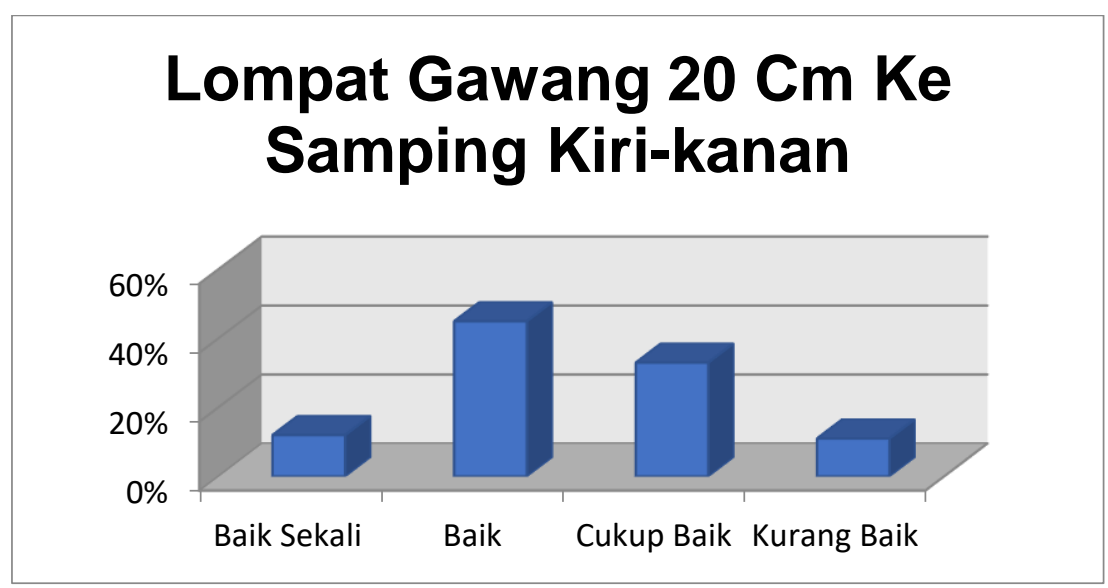

\section{Gambar 4. Sajian Hasil Analisis Data Bentuk Frekunensi Relatif dan Norma Kriteria Tes Hasil Tes Lompat Gawang $20 \mathrm{Cm}$ Ke Samping Kiri-kanan}

Berdasarkan data yang disajikan dalam bentuk Grafik 4 tersebut dapat dijelaskan bahwa data yang dianalisis melalui frekuensi relatif diantara skor-skor yang masuk dalam kelas-kelas frekuensi yang paling menonjol adalah pada kelas baik yaitu Fo berjumlah 41 (45\%) dari 92 orang dan pada baik sekali yaitu Fo yang jumlahnya paling kecil yaitu 10 (11\%) dari 92 orang. Merujuk pada Tabel 7 tersebut, dapat dikemukakan bahwa berdasarkan hasil tes lompat gawang $20 \mathrm{~cm}$ ke samping kiri-kanan keadaan keterampilan gerak lompat gawang $20 \mathrm{~cm}$ ke samping kiri-kanan pada Siswa Putra Kelas 7 MTs I Kota Malang dominan berada pada kriteria baik sekali $12 \%$, baik $45 \%$, cukup baik 33\%, dan kurang baik $11 \%$.

Tabel 8. Distribusi Frekuensi Relatif dan Kriteria Tes Loncat Side Hop Jump Data Siswa Putra Kelas 7 MTs I Kota Malang

\begin{tabular}{cccc}
\hline Interval & Fo & FR & Keterangan \\
\hline $44-49$ & 15 & $16 \%$ & Baik Sekali \\
$39-43$ & 39 & $42 \%$ & Baik \\
$34-38$ & 26 & $28 \%$ & Cukup baik \\
$29-33$ & 9 & $10 \%$ & Kurang Baik \\
$24-28$ & 3 & $3 \%$ & Tidak Baik \\
\hline
\end{tabular}

Berdasarkan sajian hasil analisis deskripsi bentuk persentase pada Tabel 8 data hasil tes loncat side ho jump dari Siswa Putra Kelas 7 MTs I Kota Malang yang berjumlah 92 orang disajikan bentuk distribusi frekuensi terdiri dari 5 kelas masing-masing kelas berinterval 5 kali. Masing-masing kelas mempunyai frekuensi dan setiap kelas yang berfrekuensi (f) dibagi dengan jumlah seluruh peserta tes 92 orang peserta. Mengacu distribusi frekuensi bergolong tersebut pada Tabel 8 tersebut, dapat dikemukakan bahwa kelas cukup baik 39 - 34 mempunyai $\mathrm{f}=39$ dari 92 orang dengan besar persentase $42 \%$ sebagai skor persentase tertinggi dan kelas baik sekali $24-28$ jumlah $f=3$ dari 92 orang dengan persentase $=3 \%$ sebagai skor terendah. 


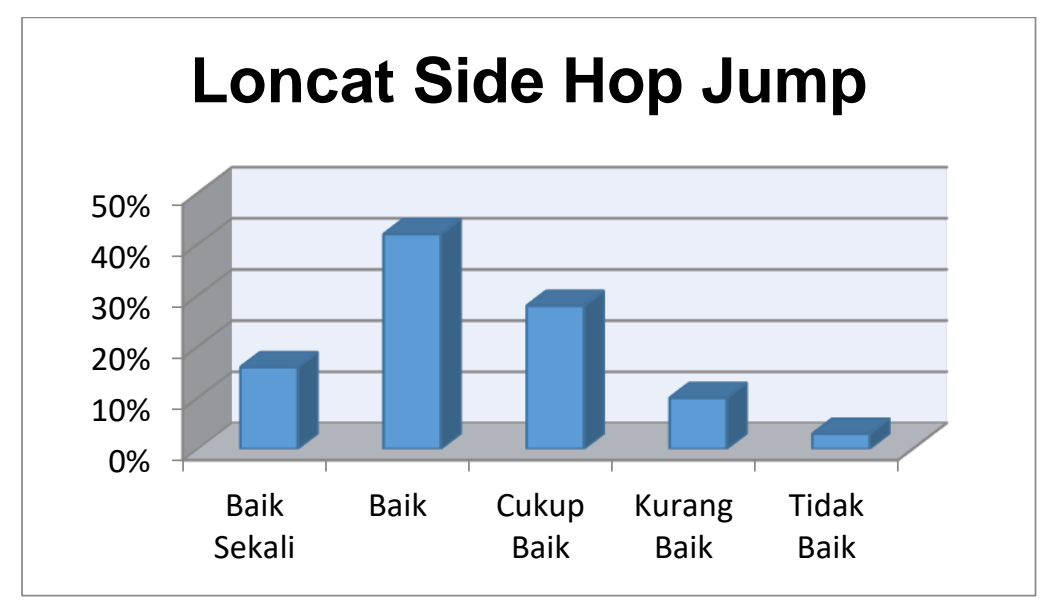

Gambar 5. Sajian Hasil Analisis Data Bentuk Frekunensi Relatif dan Norma Kriteria Tes Hasil Tes Loncat Side Hop Jump

Berdasarkan data yang disajikan dalam bentuk Grafik 5 tersebut dapat dijelaskan bahwa data yang dianalisis melalui frekuensi relatif diantara skor-skor yang masuk dalam kelas-kelas frekuensi yang paling menonjol adalah pada kelas baik yaitu Fo berjumlah 39 (42\% ) dari 92 orang dan pada tidak baik yaitu Fo yang jumlahnya paling kecil yaitu 3 (3\%) dari 92 orang. Merujuk pada Tabel 8 tersebut, dapat dikemukakan bahwa berdasarkan hasil tes loncat side hop jump keadaan keterampilan gerak loncat side hop jump pada Siswa Putra Kelas 7 MTs I Kota Malang dominan berada pada kriteria baik sekali $16 \%$, baik $42 \%$, cukup baik $28 \%$, kurang baik $10 \%$, dan tidak baik $2 \%$.

Tabel 9. Distribusi Frekuensi Relatif dan Kriteria Tes Loncat Knee Tuck Jump Data Siswa Putra Kelas 7 MTs I Kota Malang

\begin{tabular}{cccc}
\hline Interval & Fo & FR & Keterangan \\
\hline $25-30$ & 19 & $21 \%$ & Baik Sekali \\
$21-25$ & 31 & $34 \%$ & Baik \\
$16-20$ & 28 & $30 \%$ & Cukup baik \\
$11-15$ & 14 & $15 \%$ & Kurang Baik \\
\hline
\end{tabular}

Berdasarkan sajian hasil analisis deskripsi bentuk persentase pada Tabel 9 data hasil tes loncat knee tuck jump dari Siswa Putra Kelas 7 MTs I Kota Malang yang berjumlah 92 orang disajikan bentuk distribusi frekuensi terdiri dari 4 kelas masing-masing kelas berinterval 5 kali. Masing-masing kelas mempunyai frekuensi dan setiap kelas yang berfrekuensi (f) dibagi dengan jumlah seluruh peserta tes 92 orang peserta. Mengacu distribusi frekuensi bergolong tersebut pada Tabel 9 tersebut, dapat dikemukakan bahwa kelas baik $21-25$ mempunyai $\mathrm{f}=$ 31 dari 92 orang dengan besar persentase 34\% sebagai skor persentase tertinggi dan kelas kurang baik $11-15$ jumlah $\mathrm{f}=14$ dari 92 orang dengan persentase $=15 \%$ sebagai skor terendah. 


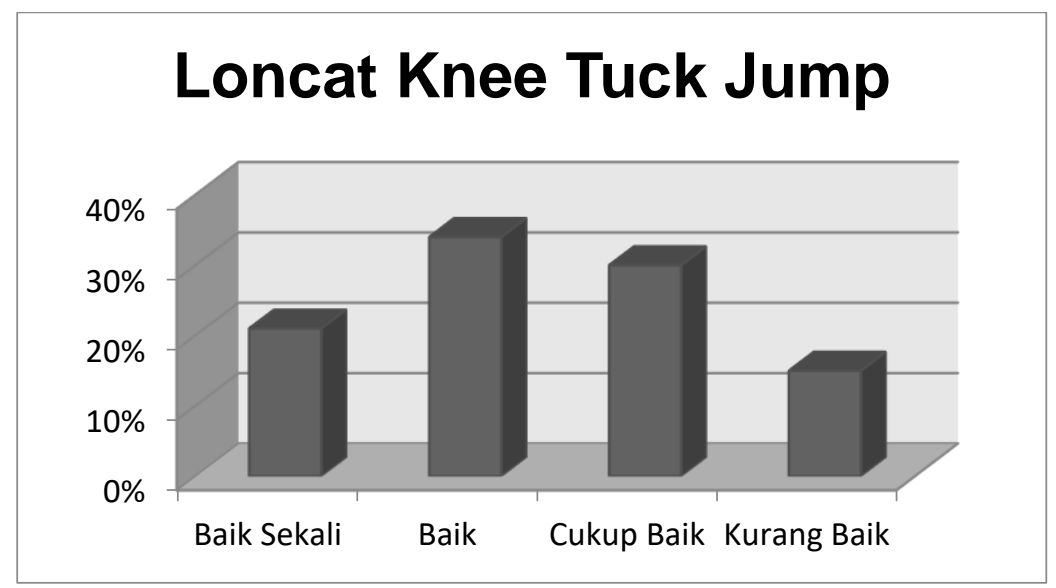

\section{Gambar 6. Sajian Hasil Analisis Data Bentuk Frekunensi Relatif dan Norma Kriteria Tes Hasil Tes Loncat Knee Tuck Jump}

Berdasarkan data yang disajikan dalam bentuk Grafik 6 tersebut dapat dijelaskan bahwa data yang dianalisis melalui frekuensi relatif diantara skor-skor yang masuk dalam kelas-kelas frekuensi yang paling menonjol adalah pada kelas baik yaitu Fo berjumlah 31 (34\% ) dari 92 orang dan pada tidak baik yaitu Fo yang jumlahnya paling kecil yaitu 14 (15\%) dari 92 orang. Merujuk pada Tabel 9 tersebut, dapat dikemukakan bahwa berdasarkan hasil tes loncat knee tuck jump keadaan keterampilan gerak loncat knee tuck jump pada Siswa Putra Kelas 7 MTs I Kota Malang dominan berada pada kriteria baik sekali $21 \%$, baik $34 \%$, cukup baik $30 \%$, dan kurang baik $15 \%$.

Tabel 10. Penyajian Hasil Analisis Data Kemampuan Gerak Dasar Nonlokomotor Pada Siswa Putra Kelas 7 MTs I Kota Malang

\begin{tabular}{|c|c|c|c|c|c|c|c|}
\hline \multirow[b]{2}{*}{ No. } & \multirow{2}{*}{$\begin{array}{l}\text { Gerak Dasar Unsur } \\
\text { Nonlokomotor }\end{array}$} & \multirow[b]{2}{*}{$\begin{array}{l}\text { Jenis } \\
\text { Tes }\end{array}$} & \multicolumn{4}{|c|}{ Ukuran Statistik } & \multirow[b]{2}{*}{ Keterangan } \\
\hline & & & $\bar{X}$ & SD & Varian & $\begin{array}{l}\mathrm{KV} \\
(\%)\end{array}$ & \\
\hline 1. & & $\begin{array}{l}\text { Sit and } \\
\text { reach }\end{array}$ & $\begin{array}{l}9,88 \\
\mathrm{~cm}\end{array}$ & $\begin{array}{l}3,92 \\
\mathrm{~cm}\end{array}$ & $\begin{array}{l}15,39 \\
\mathrm{~cm}\end{array}$ & $\begin{array}{l}40,0 \\
\%\end{array}$ & Heterogen \\
\hline 2. & & $\begin{array}{l}\text { Back up } \\
\text { lengan }\end{array}$ & $\begin{array}{l}12,08 \\
\mathrm{~cm}\end{array}$ & $\begin{array}{l}3,06 \\
\mathrm{~cm}\end{array}$ & $\begin{array}{l}9,39 \\
\mathrm{~cm}\end{array}$ & $\begin{array}{l}25,36 \\
\%\end{array}$ & heterogen \\
\hline
\end{tabular}

\footnotetext{
Keterangan:

$\overline{\boldsymbol{X}} \quad$ : rata-rata hitung

SD : standart deviasi (simpangan baku)

KV : koefisien keragaman
}

Tabel 11. Distribusi Frekuensi Relatif dan Kriteria Tes Sit And Reach Data Siswa Putra Kelas 7 MTs I Kota Malang

\begin{tabular}{cccc}
\hline Interval & Fo & FR & Keterangan \\
\hline $18-20$ & 3 & $3 \%$ & Baik Sekali \\
$14-17$ & 16 & $17 \%$ & Baik \\
$10-13$ & 24 & $26 \%$ & Cukup baik \\
$6-9$ & 36 & $39 \%$ & Kurang Baik \\
$2-5$ & 13 & $14 \%$ & Tidak Baik \\
\hline
\end{tabular}


Berdasarkan sajian hasil analisis deskripsi bentuk persentase pada Tabel 11 data hasil tes sit and reach dari Siswa Putra Kelas 7 MTs I Kota Malang yang berjumlah 92 orang disajikan bentuk distribusi frekuensi terdiri dari 5 kelas masing-masing kelas berinterval $3 \mathrm{~cm}$. Masingmasing kelas mempunyai frekuensi dan setiap kelas yang berfrekuensi (f) dibagi dengan jumlah seluruh peserta tes 92 orang peserta. Mengacu distribusi frekuensi bergolong tersebut pada Tabel 11 tersebut, dapat dikemukakan bahwa kelas kurang baik $6-9$ mempunyai $\mathrm{f}=36$ dari 92 orang dengan besar persentase 39\% sebagai skor persentase tertinggi dan kelas baik sekali 18 - 20 jumlah $\mathrm{f}=3$ dari 92 orang dengan persentase $=3 \%$ sebagai skor terendah.

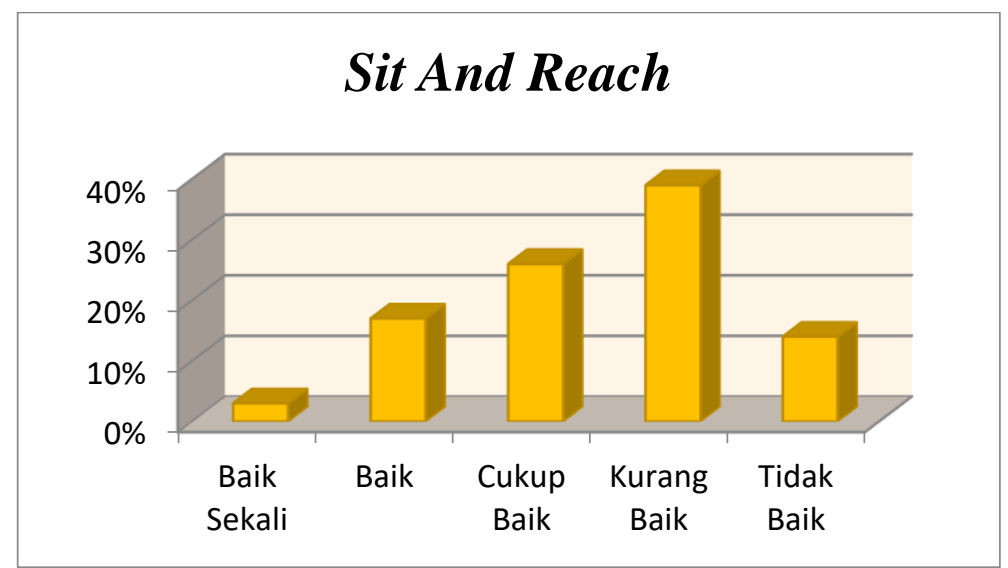

\section{Gambar 7. Sajian Hasil Analisis Data Bentuk Frekunensi Relatif dan Norma Kriteria Tes Hasil Tes Sit And Reach}

Berdasarkan data yang disajikan dalam bentuk Grafik 7 tersebut dapat dijelaskan bahwa data yang dianalisis melalui frekuensi relatif diantara skor-skor yang masuk dalam kelas-kelas frekuensi yang paling menonjol adalah pada kelas kurang baik yaitu Fo berjumlah 36 (39\% ) dari 92 orang dan pada baik sekali yaitu Fo yang jumlahnya paling kecil yaitu 3 (3\%) dari 92 orang. Merujuk pada Tabel 11 tersebut, dapat dikemukakan bahwa berdasarkan hasil tes sit and reach keadaan keterampilan gerak sit and reach pada Siswa Putra Kelas 7 MTs I Kota Malang dominan berada pada kriteria baik sekali 3\%, baik 17\%, cukup baik $26 \%$, kurang baik $39 \%$, dan tidak baik $3 \%$.

Tabel 12. Distribusi Frekuensi Relatif dan Kriteria Tes Sit And Reach Data Siswa Putra Kelas 7 MTs I Kota Malang

\begin{tabular}{cccc}
\hline Interval & Fo & FR & Keterangan \\
\hline $18-20$ & 5 & $5 \%$ & Baik Sekali \\
$15-17$ & 15 & $16 \%$ & Baik \\
$12-14$ & 28 & $30 \%$ & Cukup baik \\
$9-11$ & 33 & $36 \%$ & Kurang Baik \\
$6-8$ & 11 & $12 \%$ & Tidak Baik \\
\hline
\end{tabular}

Berdasarkan sajian hasil analisis deskripsi bentuk persentase pada Tabel12 data hasil tes back up lengan dari Siswa Putra Kelas 7 MTs I Kota Malang yang berjumlah 92 orang disajikan bentuk distribusi frekuensi terdiri dari 5 kelas masing-masing kelas berinterval $5 \mathrm{~cm}$. Masing-masing kelas mempunyai frekuensi dan setiap kelas yang berfrekuensi (f) dibagi dengan jumlah seluruh peserta tes 92 orang peserta. Mengacu distribusi frekuensi bergolong tersebut pada Tabel 12 tersebut, dapat dikemukakan bahwa kelas cukup baik $30-34$ 
mempunyai $\mathrm{f}=28$ dari 92 orang dengan besar persentase $41 \%$ sebagai skor persentase tertinggi dan kelas tidak baik $15-19$ jumlah $\mathrm{f}=4$ dari 92 orang dengan persentase $=4 \%$ sebagai skor terendah.

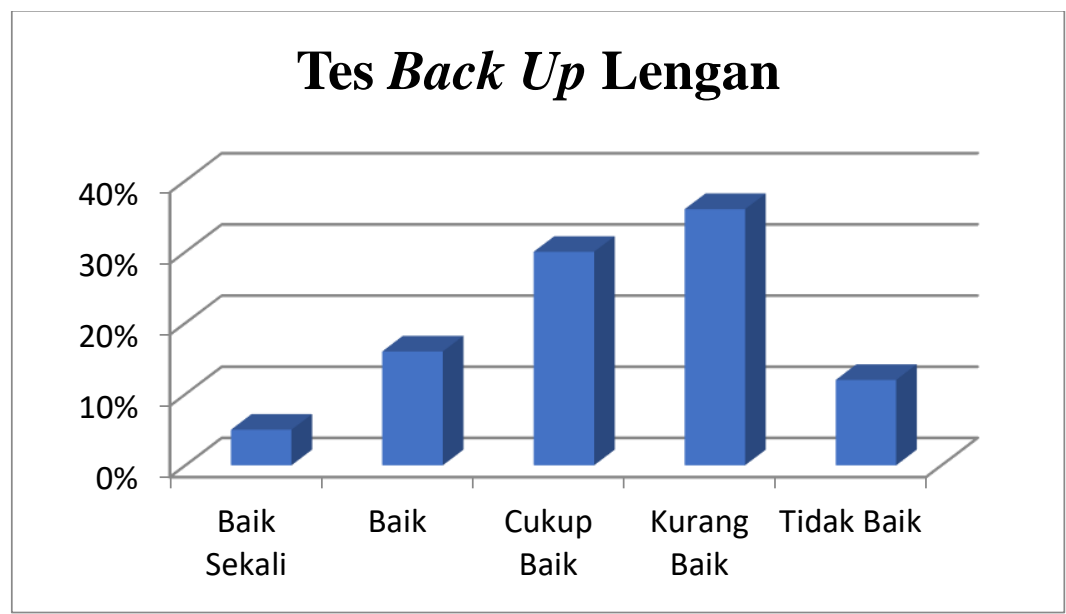

\section{Grafik 8 Sajian Hasil Analisis Data Bentuk Frekunensi Relatif dan Norma Kriteria Tes Hasil Tes Sit And Reach}

Berdasarkan data yang disajikan dalam bentuk Grafik 8 tersebut dapat dijelaskan bahwa data yang dianalisis melalui frekuensi relatif diantara skor-skor yang masuk dalam kelas-kelas frekuensi yang paling menonjol adalah pada kelas kurang baik yaitu Fo berjumlah 33 (36\% ) dari 92 orang dan pada baik sekali yaitu Fo yang jumlahnya paling kecil yaitu 5 (5\%) dari 92 orang. Merujuk pada Tabel 12 tersebut, dapat dikemukakan bahwa berdasarkan hasil tes back up lengan keadaan keterampilan gerak back up lengan pada Siswa Putra Kelas 7 MTs I Kota Malang dominan berada pada kriteria baik sekali $5 \%$, baik $16 \%$, cukup baik $30 \%$, kurang baik $36 \%$, dan tidak baik $12 \%$.

Tabel 13. Penyajian Hasil Analisis Data Kemampuan Gerak Dasar Manipulatif Pada Siswa Putra Kelas 7 MTs I Kota Malang

\begin{tabular}{|c|c|c|c|c|c|c|c|}
\hline \multirow[b]{2}{*}{ No } & \multirow[b]{2}{*}{$\begin{array}{c}\text { Gerak Dasar } \\
\text { Unsur Manipulatif }\end{array}$} & \multirow[b]{2}{*}{ Jenis Tes } & \multicolumn{4}{|c|}{ Ukuran Statistik } & \multirow[b]{2}{*}{ Keterangan } \\
\hline & & & $\overline{\boldsymbol{X}}$ & SD & Varian & $\begin{array}{c}\text { KV } \\
(\%)\end{array}$ & \\
\hline 1. & & $\begin{array}{l}\text { Lempar } \\
\text { tangkap bola } \\
\text { tenis }\end{array}$ & $\begin{array}{l}9,13 \\
\text { kali }\end{array}$ & 2,08 kali & $\begin{array}{l}4,35 \\
\text { kali }\end{array}$ & $\begin{array}{c}11,39 \\
\%\end{array}$ & Concentred \\
\hline 2. & & $\begin{array}{l}\text { Dribble bola } \\
\text { basket }\end{array}$ & $\begin{array}{c}3,77 \\
\text { detik }\end{array}$ & 0,88 detik & $\begin{array}{c}0,78 \\
\text { detik }\end{array}$ & $\begin{array}{c}23,41 \\
\%\end{array}$ & Heterogen \\
\hline 3. & & $\begin{array}{l}\text { Lempar bola } \\
\text { ke sasaran }\end{array}$ & $\begin{array}{l}6,837 \\
\text { poin }\end{array}$ & 1,61 poin & $\begin{array}{l}2,62 \\
\text { kali }\end{array}$ & $\begin{array}{c}23,68 \\
\%\end{array}$ & Concentred \\
\hline
\end{tabular}

\footnotetext{
Keterangan:

$\overline{\boldsymbol{X}} \quad$ : rata-rata hitung

SD : standart deviasi (simpangan baku)

KV : koefisien keragaman
} 
Tabel 14. Distribusi Frekuensi Relatif dan Kriteria Tes Lempar Tangkap Bola Tenis Data Siswa Putra Kelas 7 MTs I Kota Malang

\begin{tabular}{cccc}
\hline Interval & Fo & FR & Keterangan \\
\hline $13-14$ & 8 & $9 \%$ & Baik Sekali \\
$11-12$ & 19 & $21 \%$ & Baik \\
$9-10$ & 31 & $34 \%$ & Cukup baik \\
$7-8$ & 23 & $25 \%$ & Kurang Baik \\
$5-6$ & 11 & $12 \%$ & Tidak Baik \\
\hline
\end{tabular}

Berdasarkan sajian hasil analisis deskripsi bentuk persentase pada Tabel 14 data hasil tes lempar tangkap bola tenis dari Siswa Putra Kelas 7 MTs I Kota Malang yang berjumlah 92 orang disajikan bentuk distribusi frekuensi terdiri dari 5 kelas masing-masing kelas berinterval 1 kali. Masing-masing kelas mempunyai frekuensi dan setiap kelas yang berfrekuensi (f) dibagi dengan jumlah seluruh peserta tes 92 orang peserta. Mengacu distribusi frekuensi bergolong tersebut pada Tabel 14 tersebut, dapat dikemukakan bahwa kelas cukup baik $9-10$ mempunyai $f=31$ dari 92 orang dengan besar persentase $34 \%$ sebagai skor persentase tertinggi dan kelas baik sekali $13-14$ jumlah $\mathrm{f}=8$ dari 92 orang dengan persentase $=9 \%$ sebagai skor terendah.

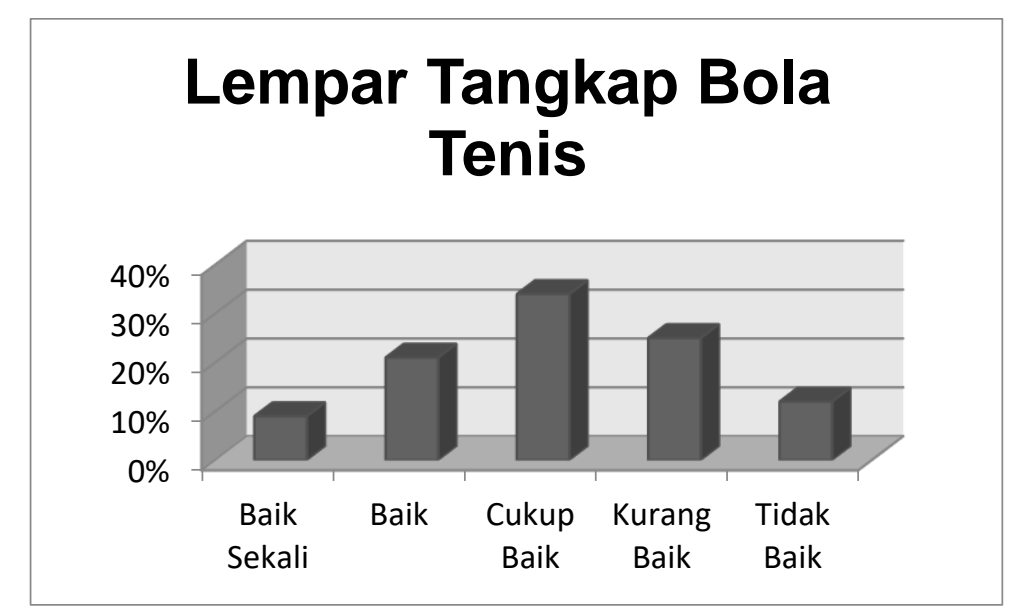

\section{Gambar 9. Sajian Hasil Analisis Data Bentuk Frekunensi Relatif dan Norma Kriteria Tes Lempar Tangkap Bola Tenis}

Berdasarkan data yang disajikan dalam bentuk Gambar 9 tersebut dapat dijelaskan bahwa data yang dianalisis melalui frekuensi relatif diantara skor-skor yang masuk dalam kelas-kelas frekuensi yang paling menonjol adalah pada kelas cukup baik yaitu Fo berjumlah $31(34 \%$ ) dari 92 orang dan pada baik sekali yaitu Fo yang jumlahnya paling kecil yaitu 8 (9\%) dari 92 orang. Merujuk pada Tabel 4.12 tersebut, dapat dikemukakan bahwa berdasarkan hasil tes lempar tngkap bola tenis keadaan keterampilan lempar tangkap bola tenis pada Siswa Putra Kelas 7 MTs I Kota Malang dominan berada pada kriteria baik sekali 9\%, baik 21\%, cukup baik $34 \%$, kurang baik $25 \%$, dan tidak baik $12 \%$. 
Tabel 15. Distribusi Frekuensi Relatif dan Kriteria Tes dribble bola basket Data Siswa Putra Kelas 7 MTs I Kota Malang

\begin{tabular}{cccc}
\hline Interval & Fo & FR & Keterangan \\
\hline $2,01-3,10$ & 9 & $10 \%$ & Baik Sekali \\
$3,11-4,20$ & 61 & $66 \%$ & Baik \\
$4,21-5,30$ & 15 & $16 \%$ & Cukup baik \\
$5,31-6,40$ & 6 & $7 \%$ & Kurang Baik \\
$6,41-7,50$ & 1 & $1 \%$ & Tidak Baik \\
\hline
\end{tabular}

Berdasarkan sajian hasil analisis deskripsi bentuk persentase pada Tabel 15 data hasil tes dribble bola basket dari Siswa Putra Kelas 7 MTs I Kota Malang yang berjumlah 92 orang disajikan bentuk distribusi frekuensi terdiri dari 5 kelas masing-masing kelas berinterval 1,1 detik. Masing-masing kelas mempunyai frekuensi dan setiap kelas yang berfrekuensi (f) dibagi dengan jumlah seluruh peserta tes 92 orang peserta. Mengacu distribusi frekuensi bergolong tersebut pada Tabel 15 tersebut, dapat dikemukakan bahwa kelas baik 3,11-4,20 mempunyai $\mathrm{f}=61$ dari 92 orang dengan besar persentase $66 \%$ sebagai skor persentase tertinggi dan kelas baik sekali $6,41-7,50$ jumlah $\mathrm{f}=1$ dari 92 orang dengan persentase $=1 \%$ sebagai skor terendah.

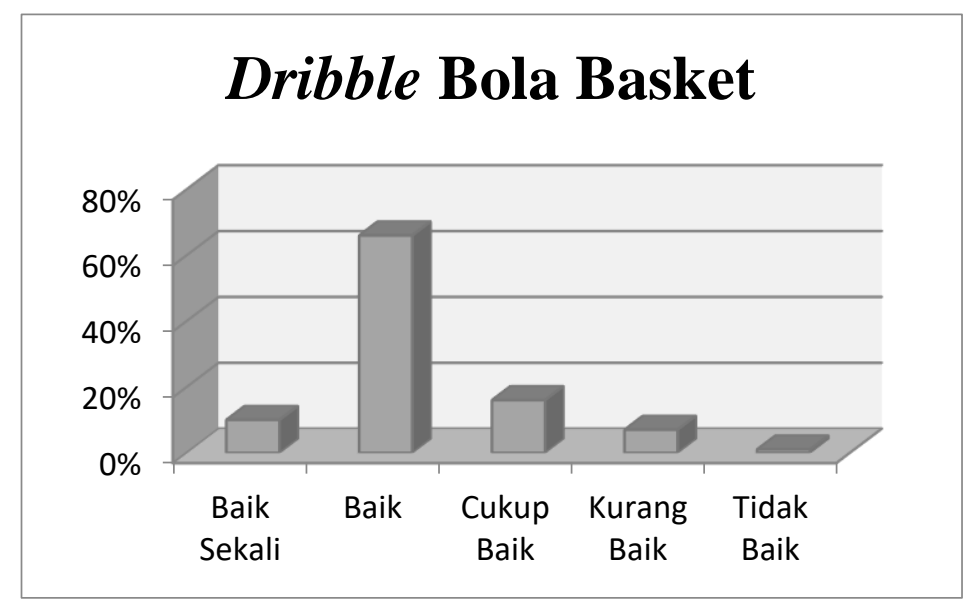

Gambar 10. Sajian Hasil Analisis Data Bentuk Frekunensi Relatif dan Norma Kriteria Tes dribble bola basket

Berdasarkan data yang disajikan dalam bentuk Grafik 10 tersebut dapat dijelaskan bahwa data yang dianalisis melalui frekuensi relatif diantara skor-skor yang masuk dalam kelas-kelas frekuensi yang paling menonjol adalah pada kelas cukup baik yaitu Fo berjumlah 61 (66\% ) dari 92 orang dan pada tidak baik yaitu Fo yang jumlahnya paling kecil yaitu $1(1 \%)$ dari 92 orang. Merujuk pada Tabel 15 tersebut, dapat dikemukakan bahwa berdasarkan hasil tes dribble bola basket keadaan keterampilan dribble bola basket pada Siswa Putra Kelas 7 MTs I Kota Malang dominan berada pada kriteria baik sekali $10 \%$, baik $66 \%$, cukup baik $16 \%$, kurang baik $7 \%$, dan tidak baik $1 \%$. 
Tabel 16. Distribusi Frekuensi Relatif dan Kriteria Tes Lempar Bola Ke Sasaran Data Siswa Putra Kelas 7 MTs I Kota Malang

\begin{tabular}{cccc}
\hline Interval & Fo & FR & Keterangan \\
\hline $9-10$ & 14 & $15 \%$ & Baik Sekali \\
$7-8$ & 34 & $37 \%$ & Baik \\
$5-6$ & 36 & $39 \%$ & Cukup baik \\
$3-4$ & 8 & $9 \%$ & Kurang Baik \\
\hline
\end{tabular}

Berdasarkan sajian hasil analisis deskripsi bentuk persentase pada Tabel 16 data hasil tes lempar bola ke sasaran dari Siswa Putra Kelas 7 MTs I Kota Malang yang berjumlah 92 orang disajikan bentuk distribusi frekuensi terdiri dari 4 kelas masing-masing kelas berinterval 2 poin. Masing-masing kelas mempunyai frekuensi dan setiap kelas yang berfrekuensi (f) dibagi dengan jumlah seluruh peserta tes 92 orang peserta. Mengacu distribusi frekuensi bergolong tersebut pada Tabel 16 tersebut, dapat dikemukakan bahwa kelas cukup baik 5 - 6 mempunyai $f=36$ dari 92 orang dengan besar persentase 39\% sebagai skor persentase tertinggi dan kelas baik sekali $3-4$ jumlah $\mathrm{f}=8$ dari 92 orang dengan persentase $=$ $8 \%$ sebagai skor terendah.

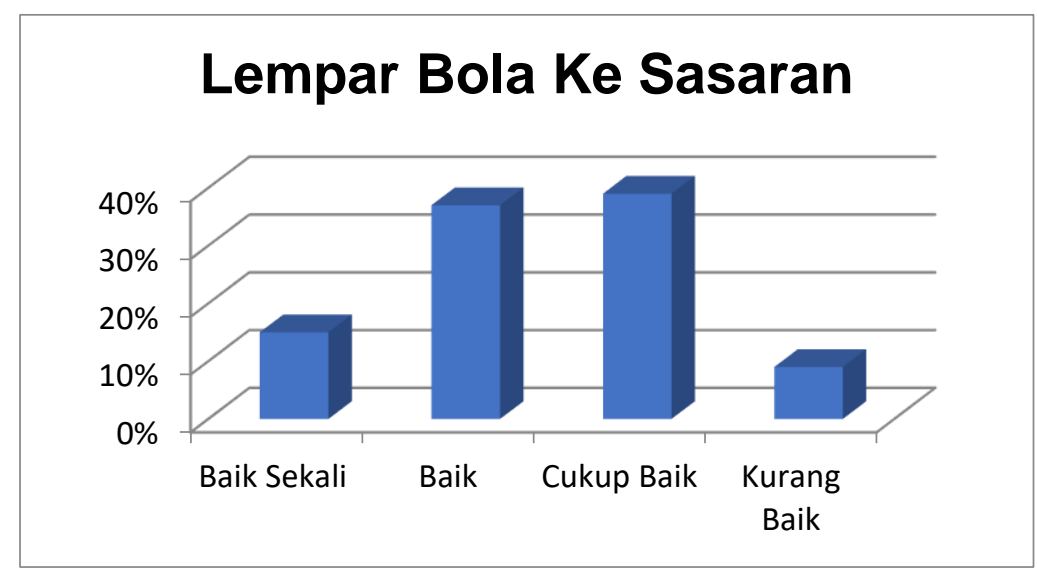

Gambar 11. Sajian Hasil Analisis Data Bentuk Frekunensi Relatif dan Norma Kriteria Tes Lempar Bola Ke Sasaran

Berdasarkan data yang disajikan dalam bentuk Grafik 11 tersebut dapat dijelaskan bahwa data yang dianalisis melalui frekuensi relatif diantara skor-skor yang masuk dalam kelas-kelas frekuensi yang paling menonjol adalah pada kelas cukup baik yaitu Fo berjumlah 36 (39\% ) dari 92 orang dan pada tidak baik yaitu Fo yang jumlahnya paling kecil yaitu 8 (9\%) dari 92 orang. Merujuk pada Tabel 16 tersebut, dapat dikemukakan bahwa berdasarkan hasil lempar bola ke sasaran keadaan keterampilan lempar bola ke sasaran pada Siswa Putra Kelas 7 MTs 1 Kota Malang dominan berada pada kriteria baik sekali 15\%, baik 37\%, cukup baik $39 \%$, dan kurang baik $8 \%$.

\subsection{Pembahasan}

\subsubsection{Keterampilan Gerak Dasar Lokomotor}

Berdasarkan data tes keterampilan gerak dasar lokomotor pada siswa putra kelas 7 di MTS Negeri 1 Kota Malang dengan hasil rata-rata kelompok tes lari 15 meter 6,83 detik dengan 
kategori baik 51 orang dengan persentase 55\% dan kategori kurang baik 41 orang dengan persentase 45\%, tes lari zigz-zag $\mathrm{M}$ run pada siswa putra dengan rata-rata 10,56 detik dengan kategori baik sekali 8 orang dengan persentase $8 \%$ dan kategori kurang baik 88 orang dengan persentase 92\%. Dari paparan untuk tes lari zig-zag dapat dilihat sangat jauh sekali perbedaan antara kategori baik sekali dengan kurang baik, hasil tersebut menunjukan bahwa faktor yang mempengaruhi kecepatan lari seorang anak baik yaitu, teknik waktu reaksi dan kemauan yang keras seta bisa juga dari keturunan dan latihan (Subroto, 2017:104). Sedangkan untuk kelincahan dikatakan baik apabila mampu mengkoordinasikan gerakan-gerakan berganda (simultan), gerakan dilakukan secara efisien, efektif dan ekonomis (Gilang 2007:58). Untuk dapat meningkatkan kemampuan gerak lokomotor unsur lari, (Septi \& Wulan, 2015) menyimpulkan bahwa proses kegiatan permainan lari estafet modifikasi merupakan salah satu cara untuk meningkatkan kemampuan gerak lokomotor, dirancang berdasarkan kurikulum yang disesuaikan dengan sekolah untuk aspek lari dalam gerak lokomotor bisa ditingkatkan melalui permainan lari estafet dengan menyesuaikan kebutuhan anak atau usia dan kurikulum yang ada dalam sekolah tersebut. Untuk tes lompat gawang $20 \mathrm{~cm}$ ke samping kiri-kanan tumpuan satu kaki memiliki rata-rata 10,55 kali dengan kategori baik sekali 52 orang dengan persentase $57 \%$ dan kurang baik 40 orang dengan persentase $40 \%$, tes lompat gawang $20 \mathrm{~cm}$ ke depan bolak-balik tumpuan satu kaki memiliki rata-rata 10,70 kali dengan kategori baik sekali 55 orang dengan persentase $60 \%$ dan kategori kurang 37 orang dengan persentase $40 \%$, tes side hop jump memiliki rata-rata 39 kali dengan kategori baik sekali 54 orang dengan persentase $58 \%$ dan kategori kurang baik 31 orang dengan persentase $42 \%$, dan tes knee tuck jump memiliki rata-rata 20,65 kali dengan kategori baik sekali 50 orang dengan persentase $55 \%$ dan kategori kurang baik 42 orang dengan persentase 45\%. Dari hasil tes lompat dan loncat yang digunakan tersebut menggunakan aspek daya ledak otot tungkai, adalah satu yang mempengaruhi lompatan tersebut adalah kurangnya daya ledak otot tungkai. Daya ledak merupakan hasil dari kekuatan dan kecepatan, contoh apabila dua orang dikatakan dapat mengangkat beban yang sama namun salah seorang tidak mampu dengan cepat mengangkat beban tersebut berarti daya ledak dikatakan kurang, begitu juga sebaliknya (Gilang, 2007).

\subsubsection{Keterampilan Gerak Dasar Nonlokomotor}

Berdasarkan data tes keterampilan gerak dasar nonlokomotor pada siswa putra kelas 7 di MTS Negeri 1 Kota Malang dengan hasil rata pada kelompok tes sit and reach 9,85 cm dengan kategori baik sekali 19 orang dengan persentase 20\% dan kategori kurang baik 73 orang dengan persentase $80 \%$ dan tes back up lengan memiliki rata-rata 29,77 cm dengan kategori baik sekali 20 orang dengan persentase $21 \%$ dan kategori kurang baik 72 orang dengan persentase 79\%. Pada kedua tes tersebut membutuhkan unsur kelentukan untuk melakukan kedua tes tersebut. Subroto (2017) mengatakan bahwa beberapa faktor yaitu struktur sendi, umur dan jenis kelamin, suhu tubuh dan suhu otot dan waktu dalam sehari-hari. Dari pendapat ahli diatas dapat dikatakan hal tersebut yang mempengaruhi kelenturan pada kedua tes tersebut.

\subsubsection{Keterampilan Gerak Dasar Manipulatif}

Berdasarkan data tes keterampilan gerak dasar manipulatif pada siswa putra kelas 7 MTs Negeri 1 Kota Malang dengan hasil rata-rata 9,31 kali dengan kategori baik sekali 27 orang dengan persentase $30 \%$ dan kategori kurang baik 65 orang dengan persentase $70 \%$, dari pembahasan hasil lempar tangkap tersebut dapat dilihat bahwa hasil belum baik, (Rahmawati, 
2017) menyimpulkan bahwa berdasarkan seluruh uraian di atas, dapat disimpulkan bahwa modifikasi merupakan salah satu alternatif kegiatan pembelajaran bagi anak yang mampu memberikan kontribusi positif untuk peningkatan kemampuan gerak manipulatif anak yang meliputi kemampuan melempar, menangkap, menendang, menggelindingkan dan mamuntal bola. Kemampuan gerak manipulatif tersebut pada hakikatnya merupakan salah satau capaian tugas perkembangan anak dalam aspek menjalani kehidupan sehari-hari. Dari beberapa penelitian terdahulu mengenai gerak dasar lokomotor, nonlokomotor, dan manipulatif yang telah dilakukan oleh Rezky (2016) dengan judul "Analisis Gerak Motorik Dasar Siswa Kelas VII Smp Negeri 1 Kecamatan Kuok Kabupaten Kampar" menyimpulkan bahwa ketiga jenis kelompok gerak dasar dijelaskan bawah gerak nonlokomotor masuk dalam kategori cukup $74,5 \%$, lokomotor dalam kategori cukup 74,5\%, dan manipulatif dalam kategori baik 85,45\%. Dari hasil analisis tidak aspek tersebut dapat diketahui kesesuaian gerak masuk dalam kategori baik 79\%. Tes dribble bola basket memiliki rata-rata 3,77 detik dengan kategori baik sekali 70 orang dengan persentase $76 \%$ dan kategori kurang baik 22 orang dengan persentase $24 \%$ dan tes lempar bola ke sasaran memiliki rata-rata 6,83 poin dengan kategori baik sekali 48 orang dengan persentase $53 \%$ dan kategori tidak baik $44 \%$ orang dengan persentase $47 \%$.

Tabel 17. Penyajian Kesimpulan Penggolongan Jenis Gerak

\begin{tabular}{|c|c|c|c|c|}
\hline No. & Jenis Gerak & Jenis Tes & Modus & Fo \\
\hline \multirow[t]{11}{*}{1.} & Lokomotor & Lari 15 meter & $\begin{array}{l}3,29 \\
\text { detik }\end{array}$ & 5 \\
\hline & & Lari zig-zag bentuk M & $\begin{array}{l}10,67 \\
\text { detik }\end{array}$ & 3 \\
\hline & & $\begin{array}{l}\text { Lompat gawang } 20 \mathrm{~cm} \text { ke ssamping kiri- } \\
\text { kanan tumpuan satu kaki }\end{array}$ & 12 kali & 19 \\
\hline & & $\begin{array}{l}\text { Lompat gawang } 20 \mathrm{~cm} \text { ke depan bolak- } \\
\text { balik tumpuan satu kaki }\end{array}$ & 12 kali & 19 \\
\hline & & Side hop jump & 39 kali & 10 \\
\hline & & Knee tuck jump & 18 kali & 9 \\
\hline & Nonlokomotor & Sit and reach & $7 \mathrm{~cm}$ & 11 \\
\hline & & Back up lengan & $10 \mathrm{~cm}$ & 11 \\
\hline & Manipulatif & Lempar tangkap bola tenis & 8 kali & 17 \\
\hline & & Dribble bola basket & $\begin{array}{l}3,11 \\
\text { detik }\end{array}$ & 6 \\
\hline & & Lempar bola ke sasaran & 6 poin & 26 \\
\hline
\end{tabular}

Dalam penyajian tabel diatas dijelaskan bahwa nilai yang sering muncul dari berbagai aspek lokomotor, nonlokomotor, dan manipulatif untuk gerak lokomotor unsur lari tes lari 15 meter menunjukkan nilai yang sering muncul yaitu 3,29 detik dengan fo=5 dominan masuk pada kriteria baik dan lari zig-zag bentuk M menunjukkan nilai yang sering muncul yakni 10,67 
detik dengan fo=3 dominan pada kriteria kurang baik. Untuk unsur lompat pada tes lompat gawang $20 \mathrm{~cm}$ ke samping kiri-kanan tumpuan satu kaki dan lompat gawang $20 \mathrm{~cm}$ ke depan bolak-balik tumpuan satu kaki nilai yang sering muncul sama yaitu $12 \mathrm{~cm}$ dengan fo=19 dominan kriteria cukup baik. Dan untuk unsur loncat tes side hop jump nilai yang sering muncul yaitu 39 kali dengan fo=10 dominan kriteria baik, dan tes knee tuck jump nilai yang sering muncul yaitu 18 kali dengan kriteria 9 dominan cukup baik. Untuk aspek nonlokomotor tes sit and reach nilai yang sering muncul $7 \mathrm{~cm}$ dengan fo= 11 dominan kriteria kurang baik dan untuk tes back up lengan nilai yang sering muncul yaitu $10 \mathrm{~cm}$ dengan fo= 11 dominan kriteria kurang baik. Dan untuk aspek manipulatif tes lempar tangkap bola tenis nilai yang sering muncul yaitu 8 kali dengan fo=17 dominan kriteria kurang baik, untuk tes dribble bola basket nilai yang sering muncul yaitu 3,11 detik dengan fo= 6 dominan kriteria cukup baik, dan untuk tes lempar bola ke sasaran nilai yang sering muncul yaitu 6 poin dengan fo $=26$ dominan kriteria kurang baik. Dari paparan hasil dari tes gerak lokomotor, nonlokomotor, dan manipulatif, Mengetahui perbedaan kemampuan motorik seperti kemampuan gerak dasar siswa dapat membantu pendidik dalam merencanakan pembelajaran dan mempraktikkan pengalamannya sebagai titik awal untuk penilaian penampilan pada siswa (Rahyubi, 2014). Sehubungan dengan hasil dominan tidak baik tersebut berarti guru penting ke depan merancang pembelajaran PJOK yang sistematis dan tertata dengan baik. Simanjuntak, dkk. (2010) yang mengatakan bahwa gerak bagi anak sebagai aktivitas jasmani merupakan salah satu tuntutan kebutuhan hidup yang diperlukan, yaitu sebagai dasar untuk belajar dalam usaha untuk memperoleh berbagai pengalaman berupa pengetahuan dan keterampilan yang akan digunakan dalam mengatasi perubahan-perubahan yang terjadi di lingkungannya. Pendapat tersebut dapat dikemukakan bahwa pembelajaran pendidikan jasmani merupakan suatu proses menguntungkan bagi siswa dari belajar gerak melalui aktivitas fisik untuk memperoleh pengalaman pengetahuan dan keterampilan untuk menunjang kehidupan mereka.

\section{Simpulan}

Berdasarkan hasil dan pembahasan penelitian ini dapat disimpulkan bahwa, kemampuan gerak dasar lokomotor yang dibagi menjadi 3 unsur gerak yaitu lari,lompat dan loncat. Lari di antaranya lari 15 dengan kategori cukup baik dan lari zig-zag dengan kategori tidak baik, lompat terdiri dari gawang $20 \mathrm{~cm}$ ke samping kiri-kanan satu kaki masuk kategori cukup baik dan lompat gawang $20 \mathrm{~cm}$ ke depan bolak-balik tumpuan satu kaki masuk kategori baik. Dan loncat side hop jump masuk kategori cukup baik dan loncat knee tuck jump masuk kategori cukup baik. Kemampuan gerak dasar nonlokomotor yang dibagi 2 unsur gerak yaitu sit and reach dengan kategori kurang baik dan back up lengan serta untuk kemampuan gerak dasar manipulatif yang dibagi menjadi 3 unsur gerak yaitu, lempar tangkap bola tenis dengan kategori kurang baik , dribble bola basket dengan kategori baik, dan lempar bola ke sasaran dengan kategori cukup baik.

\section{Daftar Rujukan}

Afandi, A. (2019). Buku Ajar Pendidikan dan Perkembangan Motorik. Sidoarjo: Uwais Inspirasi Indonesia.

Argasasmita, H. (2007). Teori Kepelatihan Dasar. Jakarta: Kementerian Pemuda dan Olahraga.

Baumgartner, T.A. \& Hensley, L.D. (2006), Conducting and Reading Research in Healt and Human Performance. $4^{\text {th }}$. Santiago: McGraw Hill Companies.

Buck, M. M., Lund, J. L., Harrison, J. M., \& Cook, C. B, (2007). Instructional Strategies for Secondary School Physical Education. New York. McGraw-Hill.

Husdarta. H. J. S. (2011). Manejemen Pendidikan Jasmani. (Cetakan Kesatu). Bandung: Alfabeta. 
Kadir. (2015). Statistika Terapan. Konsep, Contoh dan Analisis Data dengan Program SPSS dalam Penelitian. Jakarta: Raja Grafindo Persada.

Kadir. (2018). Statistika Terapan. Konsep, Contoh dan Analisis Data dengan Program SPSS dalam Penelitian. Jakarta: Raja Grafindo Persada.

Kamid, M. A., Hariyanto, N., Kartono, \& Suwartono. (2017). Statistika Pendidikan. Jakarta: Universitas Terbuka.

Lefudin. (2017). Belajar \& Pembelajaran. cetakan kedua. Yogyakarta: Deepublish.

Lumintuarso, R. (2013). Pembinaan Multilateral Bagi Atlet Pemula. Yogyakarta. UNY Press.

Mairing, J. P. (2017). Statistika Pendidikan. Konsep dan Penerapannya Menggunakan Minitab dan Microsoft Excel. Yogyakarta: Andi Office.

Maolani, R.A \& Cahyana, U. 2015. Metodologi Penelitian Pendidikan. Jakarta. PT Rajagrafindo Persada.

Mirawati, M., \& Rahmawati, E. (2017). Permainan Modifikasi untuk Stimulasi Keterampilan Gerak Dasar Manipulatif Anak Usia 2-4 Tahun. Early Childhood: Jurnal Pendidikan, 1(2), 38-50.

Mukholid, A. (2007). Pendidikan Jasmani Olahraga \& Kesehatan SMA Kelas XI 2. Yudhistira.

Mulyanto, R. (2014). Belajar dan Pembelajaran penjas. Bandung: UPI.

Nurrochmah, S. (2016). Tes dan Penggukuran Dalam Pendidikan Jasmani \& Keolahragaan. Malang: Universitas Negeri Malang.

Prastowo, A. (2019). Analisis Pembelajaran Tematik Terpadu. Jakarta: Prenandamedia.

Rahyubi, H. (2012). Teori-Teori Belajar dan Aplikasi Pembelajaran Motorik. Bandung: Nusa Media Ujungberung.

Rahyubi, H. (2014). Teori-Teori Belajar dan Aplikasi Pembelajaran Motorik. Bandung: Nusa Media Ujungberung.

Rezki, R. (2016). Analisis Gerak Motorik Dasar Siswa Kelas VII SMP Negeri 1 Kecematan Kuok Kabupaten Kampar. Journal Sport Area. 1 (1), 63.

Rusman. K, Deni \& Riyana, C. (2012). Pembelajaran Berbasis Teknologi informasi dan Komunikasi. Jakarta: PT RajaGrafindo Persada.

Simanjuntak, V. G. (2008). Pendidikan Jasmani dan Kesehatan. Direktorat Jendral Pendidikan tinggi Departemen Pendidikan Nasional.

Subroto, T. (2008). Strategi Pembelajaran Penjas. Jakarta: Universitas Terbuka.

Sudarsini, (2016). Modul Gerak Dasar dan Gerak Irama. Malang. Gunung Samudara.

Sudirjo, E \& Alif, M.U. (2018). Pertumbuhan dan Perkembangan Motorik. Sumedang: UPI sumedang Press.

Sukmadinata, N. S. (2013). Metodologi Penelitian Pendidikan. Bandung. PT Remaja Rosdakarya.

Syahrial, B. (2015). Merancang Pembelajaran Gerak Dasar Anak. Padang. UNP Press.

Thobroni, M. \& Mustofa, A. (2013). Belajar dan Pembelajaran. pengembangan Wacana dan Praktik Pembelajaran dalam Pembangunan Nasional. Yogyakarta: AR Ruzz Media.

Wulan, D. S. A. (2015). Peningkatan Kemampuan Gerak Lokomotor melalui Permainan Lari Estafet Modifikasi. Jurnal Pendidikan Usia Dini, 9(1), 163-180.

Wiarto, G. (2015). Inovasi Pembelajaran dalam Pendidikan Jasmani. Yogyakarta: Laksitas. 